$1-9-2016$

\title{
Religious Institutionalism in a Canadian Context
}

Victor M. Muñiz-Fraticelli

McGill University

Lawrence David

McGill University

Follow this and additional works at: https://digitalcommons.osgoode.yorku.ca/ohlj

Part of the Constitutional Law Commons, and the Religion Law Commons Article

\section{(c) (1) $(9)$}

This work is licensed under a Creative Commons Attribution-Noncommercial-No Derivative Works 4.0 License.

\section{Citation Information}

Muñiz-Fraticelli, Victor M. and David, Lawrence. "Religious Institutionalism in a Canadian Context." Osgoode Hall Law Journal 52.3 (2015) : 1049-1114.

https://digitalcommons.osgoode.yorku.ca/ohlj/vol52/iss3/9

This Article is brought to you for free and open access by the Journals at Osgoode Digital Commons. It has been accepted for inclusion in Osgoode Hall Law Journal by an authorized editor of Osgoode Digital Commons. 


\title{
Religious Institutionalism in a Canadian Context
}

\author{
Abstract \\ Does freedom of religion protect religious institutions or does it only protect the individual religious \\ conscience? Canadian jurisprudence after the enactment of the Canadian Charter of Rights and \\ Freedoms takes a decidedly individualist turn, deliberately avoiding the question of the rights of religious \\ institutions. This individualist focus neglects the historical trajectory of religious freedom, the social \\ understanding of religious faith by religious adherents themselves, and the institutional structures in \\ which religion emerges and develops (and through which it is ultimately protected). An institutional \\ account of religious liberty can complement the individualist account, as it better explains the legal order, \\ better reflects actual religious practice, and better preserves both institutional and individual religious \\ liberty. Recent decisions of the Supreme Court of Canada go some way towards correcting this \\ individualist bias but balk at resolving the legal status of religious institutions. This persistent ambiguity \\ will prove problematic in controversies over religious autonomy already making their way through the \\ courts.
}

\section{Keywords}

Canada. Canadian Charter of Rights and Freedoms; Freedom of religion; Religious institutions--Law and legislation; Canada

\section{Creative Commons License}

\section{(c) $(i) \Theta \Theta$}

This work is licensed under a Creative Commons Attribution-Noncommercial-No Derivative Works 4.0 License. 


\title{
Religious Institutionalism in a Canadian Context
}

\author{
VICTOR M. MUÑIZ-FRATICELLI* \& LAWRENCE DAVID**
}

Does freedom of religion protect religious institutions or does it only protect the individual religious conscience? Canadian jurisprudence after the enactment of the Canadian Charter of Rights and Freedoms takes a decidedly individualist turn, deliberately avoiding the question of the rights of religious institutions. This individualist focus neglects the historical trajectory of religious freedom, the social understanding of religious faith by religious adherents themselves, and the institutional structures in which religion emerges and develops land through which it is ultimately protected). An institutional account of religious liberty can complement the individualist account, as it better explains the legal order, better reflects actual religious practice, and better preserves both institutional and individual religious liberty. Recent decisions of the Supreme Court of Canada go some way towards correcting this individualist bias but balk at resolving the legal status of religious institutions. This persistent ambiguity will prove problematic in controversies over religious autonomy already making their way through the courts.

La liberté de religion protège-t-elle les institutions religieuses ou uniquement la conscience religieuse individuelle? Depuis la promulgation de la Charte canadienne des droits et libertés, la jurisprudence canadienne prend décidément une tournure vers l'individualisme et évite délibérément la question des droits des institutions religieuses. Cette mise à l'avant-scène de l'individualisme néglige l'évolution historique de la liberté de religion, l'interprétation sociale que se font de leur foi les fidèles eux-mêmes et la structure institutionnelle dans laquelle prend forme et se développe la religion, structure qui permet de la protéger. Un

* Associate Professor, Department of Political Science and Faculty of Law, McGill University. Work on this article was supported, in part, by an Insight Development Grant from the Social Sciences and Humanities Research Council. Simon Ayotte, Tara Mrejen, John-Andrew Petrakis, Larissa Smith, and Kayle Sykes provided valuable research assistance.

** BCL/LLB, McGill University. Work on this article was supported, in part, by a Borden Ladner Gervais student research fellowship. Mr. David took no part in the editorial process after July $14,2015$. 
1050 (2015) 52 OSGOODE HALL LAW JOURNAL

constat institutionnel de la liberté de religion peut compléter le constat individualiste, car il explique mieux l’ordre juridique, reflète mieux la pratique religieuse véritable et protège mieux la liberté de religion tant individuelle qu'institutionnelle. Des jugements récents de la Cour suprême du Canada concourent à corriger ce parti pris individualiste, mais rechignent à résoudre le statut juridique des institutions religieuses. Cette ambigüité persistante posera problème pour résoudre la controverse entourant l'autonomie religieuse, qui est de plus en plus soumise aux tribunaux.

I. AN INSTITUTIONALIST ACCOUNT OF FREEDOM OF RELIGION $\ldots \ldots \ldots \ldots . \ldots 1053$

II. RELIGIOUS INSTITUTIONALISM AND THE CONCEPT OF FREEDOM OF RELIGION .................... 1057

III. RELIGIOUS INSTITUTIONALISM AND THE HISTORY OF FREEDOM OF RELIGION...................... 1066

IV. RELIGIOUS INSTITUTIONALISM AND CANADIAN CONSTITUTIONAL HISTORY......................... 1074

V. RELIGIOUS INSTITUTIONALISM IN THE POST-CHARTER ERA ............................................... 1080

A. $\quad$ Big $M$ and the Individualization of Religion ........................................................... 1081

B. Edwards, Hy \& Zel's, and the Religious Liberty of the Corporation ............................... 1084

C. Trinity Western and the Irreducibility of Institutional Concerns...................................... 1089

D. Amselem and the Subjectivization of Religion ..................................................... 1091

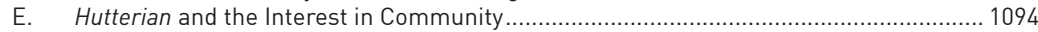

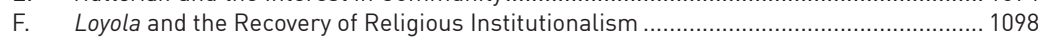

1. Education and Religion in Quebec ........................................................ 1099

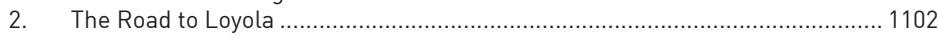

3. The Road from Loyola.......................................................................... 1107

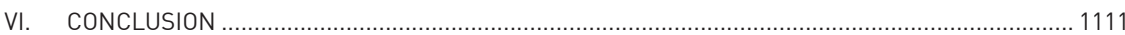

DOES FREEDOM OF RELIGION protect religious institutions or does it only protect the individual religious conscience? The question has gained increasing importance in recent years, as religious organizations have sought exemption from a variety of generally applicable laws and regulations or have demanded deference to their internal structures of governance in matters of internal dispute. 
Recent judicial decisions, ${ }^{1}$ legislative initiatives, ${ }^{2}$ and policy recommendations ${ }^{3}$ in both the United States and the European Union suggest that "there is no more important issue in law and religion today than institutional religious autonomy." 4

In Canada, legislative and jurisprudential practices have long recognized and made room for religious institutions, but the historical, conceptual, and doctrinal grounds for recognition have not been subject to sustained theoretical and normative inquiry. Before the adoption of the Canadian Charter of Rights and Freedoms ("Charter") in 1982, little attention was paid to whether religious institutions themselves were the subjects of rights and could claim the protection of religious liberty-intrinsically or as mediating entities necessary for the full exercise of the religion of individual congregants - or whether all religious rights could be reduced to the protection of conscience. The prevalence of official support for religious bodies, some of which derived direct financial support from the state both before and after Confederation, further obscured any theoretical discussion of the rights of religious institutions. ${ }^{6}$

After the Charter, the judicial discourse around freedom of religion in Canada took a decidedly individualist turn. "This Court," writes Justice Iacobucci in Syndicat Northcrest v Amselem, "has long articulated an expansive definition of

1. See Zachary R Calo, "Constructing the Secular: Law and Religion Jurisprudence in Europe and the United States" (2014) European University Institute Working Paper No RSCAS 2014/94. Calo cites a number of United States Supreme Court cases. See Hosanna-Tabor Evangelical Lutheran Church and School v Equal Employment Opportunity Commission, 565 US __ (2012) [Hosanna-Tabor]; Burwell v Hobby Lobby Stores, Inc, 573 US __ (2014) [Burwell]. Calo also cites a number of cases from the European Court of Human Rights. See Obst v Germany, No 425/03 (23 September 2010); Schüth v Germany, No 1620/03 (23 September 2010); Siebenhaar v Germany, No 18136/02 (3 February 2011); Fernández Martínez v Spain, No 56030/07 (12 June 2014).

2. For United States statutes, see e.g. Religious Freedom Restoration Act, USC tit $42 \$ 2000 \mathrm{bb}-1$ (1993) [Restoration Act]; Religious Land Use and Institutionalized Persons Act, USC tit $42 \$$ 2000cc (2000) [Land Use Act]. European legislation on the subject varies widely by country.

3. See e.g. Organization for Security and Co-operation in Europe, Office for Democratic Institutions and Human Rights, Guidelines for Review of Legislation Pertaining to Religion or Belief (Venice: OSCE/ODIHR, 2004); Organization for Security and Co-operation in Europe, Office for Democratic Institutions and Human Rights, Guidelines on the Legal Personality of Religious or Belief Communities (Warsaw: OSCE/ODIHR, 2014).

4. Calo, supra note 1 at 15 .

5. Part I of the Constitution Act, 1982, being Schedule B to the Canada Act 1982 (UK), 1982, c 11 [Charter].

6. See e.g. Dobie v Presbyterian Church of Canada, [1882] UKPC 4, 7 AC 136 [Dobie] (regarding the allocation of assets and government emoluments of the Presbyterian Church after Confederation, which the Privy Council decided primarily on the provincial authority to amend or repeal pre-Confederation statutes). 
freedom of religion, which revolves around the notion of personal choice and individual autonomy and freedom."' The Supreme Court of Canada has had several opportunities to resolve the question of whether freedom of religion protects religious institutions, but it has avoided giving a direct answer. This silence has resulted, at times, in doctrinal confusion and recurrent controversies, prominent subjects of which include Trinity Western University ("TWU") (first over its teacher training program and currently over its establishment of a Christian law school) ${ }^{8}$ and Loyola High School in Montreal (in relation to which the Court put the question of institutional freedom of religion to the parties but split on whether and how to answer the question). ${ }^{9}$

A purely individualist conception of freedom of religion is broad, but it is also shallow. It accepts a wide scope of practices and beliefs as deserving protection but does not consider the historical trajectory of religious freedom or religious adherents' social understanding of religious faith. Nor does it consider the institutional structures in which religious practice emerges and develops and through which it is ultimately protected-structures that are sometimes constitutive of religious practice. Because of this limitation, a purely individualist conception of freedom of religion excludes important manifestations of religious life in Canada, and does so unequally, since it privileges certain modes of belief and forms of organization over others. More importantly, an individualist conception renders unintelligible much of the law applicable to religious freedom and makes resolution of some controversies more difficult by denying the courts important conceptual instruments. As a result, judicial emphasis on the individual aspects of religious liberty and inattention to institutional practice have created incongruence between legal discourse and practice, ignored actual religious traditions, and potentially undermined, rather than preserved, religious freedom.

We do not mean to give an exhaustive account of all legislation and case law pertaining to religious organizations in Canada. ${ }^{10}$ Indeed, our thesis is not that

7. 2004 SCC 47 at para 40, [2004] 2 SCR 551 [Amselem], citing Rv Big M Drug Mart Ltd, [1985] 1 SCR 295, 18 DLR (4th) 321 [Big M].

8. For the teacher training program, see British Columbia College of Teachers $v$ Trinity Western University, 2001 SCC 31, [2001] 1 SCR 772 [Trinity Western] (approving the program but not deciding whether TWU could claim section 2(a) protection). For a discussion on the legal debate surrounding TWU's law school, see Elaine Craig, "The Case for the Federation of Law Societies Rejecting Trinity Western University's Proposed Law Degree Program" (2013) 25:1 CJWL 148; Dwight Newman, "On the Trinity Western University Controversy: An Argument for a Christian Law School in Canada” (2013) 22:3 Const Forum Const 1.

9. Loyola High School v Quebec (Attorney General), 2015 SCC 12, [2015] 1 SCR 613 [Loyola].

10. For a most thorough account, see MH Ogilvie, Religious Institutions and the Law in Canada, 3rd ed (Toronto: Irwin Law, 2010). 
the institutionalist perspective would have changed the outcome in any given case decided after the adoption of the Charter - the nature of most of those controversies allowed the Court to sidestep the institutional issue. Rather, we argue that the sole focus on individual religious freedom has distorted the law's apprehension of religious experience. ${ }^{11}$ We merely seek to introduce an alternative account of the proper objects of protection under the constitutional guarantee of freedom of religion and to demonstrate that this account, as a complement to constitutional theory, better explains the present legal order, better reflects actual religious practice, and better preserves both institutional and individual religious freedom. We do this, first, by briefly introducing the religious institutionalist position and distinguishing it from its contrary; second, by presenting a theoretical or conceptual account of the institutional dimension of religion; third, by proposing a historical reconstruction of the concept of religious freedom that demonstrates the centrality of its institutional protections; and finally, by tracing the institutional protection of religion though Canadian jurisprudence from Confederation, though the Charter era, to present controversies.

\section{AN INSTITUTIONALIST ACCOUNT OF FREEDOM OF RELIGION}

As we said, attention to the institutional aspects of freedom of religion complements, rather than supplants, the current exclusive focus on individual religious belief. It nonetheless requires that we consider different ways of thinking about how religious freedom has been historically understood and about the values and practices that it has been intended to protect. The autonomy of religious institutions before the civil power has been the subject of legal, political, and theological argument for centuries, both in movements that reaffirmed the claims of religious institutions and those that, while acknowledging those claims, opposed their legal recognition. Yet what we refer to as "religious institutionalism" - a standpoint in normative legal theory concerned with the structure and content of freedom of religion-is relatively recent.

Religious institutionalism refers to a family of arguments that affirms, albeit on diverse grounds, that the legal principle of religious liberty protects and ought

11. This presents a problem for coming controversies, some already in the courts, where the issues at stake involve the ability of religious institutions (i.e., schools, charities) to thrive while preserving their autonomy in the face of state regulation or where congregants dispute control of the institution with the leadership. These issues deserve thorough discussion but are beyond the present article's scope. 
to protect religious organizations directly, allowing them to claim rights that are not reducible to or directly derived from the individual rights of their members. ${ }^{12}$ The institutionalist position was first articulated in American jurisprudence over three decades ago and has gained increasing academic, legislative, and judicial support. In one of the first explicit statements interpreting the US Constitution to recognize an institutional dimension, Douglas Laycock argued that " $[\mathrm{t}]$ here is a right to church autonomy in the free exercise clause [of the US Constitution]. ... Any interference with the autonomy of these organizations jeopardizes free exercise rights of their members, including the free development of religious doctrine." ${ }^{13}$ Some other scholars (and lately, Laycock himself) also argued that government interference with religious institutions did not only violate the right of individual believers to practice their faith in associations but also contravened the prohibition on state establishment of religion. ${ }^{14}$ Thus Carl Esbeck observes that "[ $t$ ]he logic of the [US Supreme] Court's opinions inexorably leads to the conclusion that religious organizations have ... a unique institutional competency, not the mere sum of the derivative rights of their individual members." 15

More recently, religious institutionalist scholars have taken a more abstract philosophical and historical approach that makes their argument more readily applicable across national borders. These scholars defend the constitutional protection of institutional religious freedom because it inhibits the state from asserting "jurisdiction over the transcendent and extra-temporal commitments of its citizens, ${ }^{\prime 16}$ because it captures the full meaning of religious liberty as it

12. Over the last thirty years, there has been an explosion in religious institutionalist scholarship, mainly in the United States. For both sides of the debate, see Richard C Schragger \& Micah Schwartzman, "Against Religious Institutionalism" (2013) 99:5 Va L Rev 917 [Schragger \& Schwartzman, "Against"]; Paul Horwitz, "Defending (Religious) Institutionalism" (2013) 99:5 Va L Rev 1049 (2013).

13. "Towards a General Theory of the Religion Clauses: The Case of Church Labor Relations and the Right to Church Autonomy" (1981) 81:7 Colum L Rev 1373 at 1416-17. The Free Exercise Clause is one of the two aspects of religious freedom in the US Constitution, the other being the Establishment Clause. Together, they read, "Congress shall make no law respecting an establishment of religion, or prohibiting the free exercise thereof." See US Const amend I.

14. Douglas Laycock, "Church Autonomy Revisited" (2009) 7 Geo JL \& Pub Pol'y 253.

15. "The Establishment Clause as a Structural Restraint on Governmental Power" (1989) 84:1 Iowa L Rev 1 at 54

16. Ira C Lupu \& Robert W Tuttle, "The Distinctive Place of Religious Entities in Our Constitutional Order" (2002) 47:1 Vill L Rev 37 at 40. 
has historically developed though concepts like libertas ecclesiae, ${ }^{17}$ or because it recognizes the actual context in which religious beliefs and practices emerge. ${ }^{18}$

Religious institutionalism is contrasted to religious individualism, which understands religious liberty as protecting only the individual in his or her religious conscience and practices and assumes that any rights of religious organizations are ultimately reducible to rights-claims that can be entirely protected through the individual rights of members. The articulation of the religious institutionalist position has provoked opposition from scholars who take issue with ontological claims about the status of religious groups as rights-bearers, the historical and theological bases of church autonomy, and the special solicitude that religion received in American (and Canadian) law. ${ }^{19}$ Some of these disagreements go directly to the question of whether organizations can possess the attributes (moral, psychological, or otherwise) that qualify them as potential rights-bearers. ${ }^{20}$ Most critiques, however, are concerned instead with the effects that greater protection of religious institutions would have on public policy, especially the application of anti-discrimination and health benefits laws to employees, the offering of services to the general public, and the liability of churches and ministers for tortious conduct. ${ }^{21}$ In addition, the strongly institutionalist account is subject to vigorous debate in cases of church schism, in which one party might raise the

17. Richard W Garnett, "Religious Freedom, Church Autonomy, and Constitutionalism" (2009) 57 Drake L Rev 901; Richard W Garnett, "Do Churches Matter? Towards an Institutional Understanding of the Religion Clauses" (2008) 53:2 Vill L Rev 273.

18. Paul Horwitz, First Amendment Institutions (Cambridge, Mass: Harvard University Press, 2012) at 174-93 [Horwitz, First Amendment].

19. Schragger and Schwartzman, "Against," supra note 12; Richard Schragger \& Micah Schwartzman, "Some Realism about Corporate Rights" in Micah Schwartzman, Chad Flanders \& Zoë Robinson, eds, The Rise of Corporate Religious Liberty (Oxford: Oxford University Press, 2016) 345; Richard C Schragger \& Micah Schwartzman, "Lost in Translation: A Dilemma for Freedom of the Church" (2013) 21:1 J Contemp Legal Issues 165; Micah Schwartzman, "What If Religion Isn't Special?" (2012) 79:4 U Chicago L Rev 1351; Frederick Mark Gedicks, "Dignity, History, and Religious-Group Rights" (2013) 21 J Contemp Legal Issues 273; Frederick Mark Gedicks "True Lies: Canossa As Myth" (2013) 21 J Contemp Legal Issues 133.

20. See Victor M Muñiz-Fraticelli, The Structure of Pluralism (Oxford: Oxford University Press, 2014) ch 10 at 199ff [Muñiz-Fraticelli, Pluralism].

21. Chad Flanders, Micah Schwartzman \& Zoë Robinson, "Introduction" in Schwartzman, Flanders \& Robinson, eds, supra note 19, xiii; Schragger \& Schwartzman, "Against," supra note 12; Frederick Mark Gedicks \& Rebecca G Van Tassell, "RFRA Exemptions from the Contraception Mandate: An Unconstitutional Accommodation of Religion” (2014) 49:2 Harv CR-CLL Rev 343; Frederick Mark Gedicks, "Narrative Pluralism and Doctrinal Incoherence in Hosanna-Tabor" (2012) 64:2 Mercer L Rev 405; Marci A Hamilton, "Church Autonomy is Not a Better Path to "Truth”' (2006) 22:1 JL \& Religion 215. 
defence of the religious organization's institutional autonomy while the other grounds its claim on the institution being reducible to the voluntary association of individual congregants. ${ }^{22}$

The institutionalist and individualist accounts of freedom of religion both express important aspects of the concept-or rather concepts—of religious freedom in the Western legal tradition. Each captures an important dimension of religious practice and belief, but neither captures the phenomenon fully. Canadian law bearing on freedom of religion contains both individualist and institutionalist features, and the values it enshrines can be traced to one or the other concept of religious liberty. While it is theoretically possible to imagine a controversy that can be understood mostly in terms of one concept—say, a "solitary seeker" with no intent to proselytize or join with others in worship and who has little use for institutional conceptions ${ }^{23}$-most controversies will involve both concepts. For instance, hierarchical churches are often sustained by their adherents' belief in the sacramental character of the churches' structure of authority; religious groups with a distinct legal tradition depend on specialized courts to resolve disputes between adherents; and all religious organizations require some formal social activity as a constitutive condition of religious practice. These institutional aspects of religion cannot be enacted by individual consciences. Often they will be as central to the faith as any substantive affirmations of religious doctrine or creed; in many cases, serious adherence to discipline or earnest obedience to authority may define religious membership more than sincere belief. An institutional account of religion can apprehend this facet of religion in a way that an individualist

22. See e.g. Jeffrey Hassler, "A Multitude of Sins? Constitutional Standards for Legal Resolution of Church Property Disputes in a Time of Escalating Intradenominational Strife" (2008) 35:2 Pepp L Rev 399 at 402; Cameron Ellis, "Church Factionalism and Judicial Resolution: A Reconsideration of the Neutral-Principles Approach" (2009) 60:4 Ala L Rev 1001 at 1007. We will sometimes refer to religious institutions and religious officials as "ecclesiastical" and to religious bodies as "churches" in keeping with the literature on the subject, but this is not meant to exclude religious organizations that do not use these terms in self-description.

23. See e.g. Martha Nussbaum, Liberty of Conscience (Cambridge, Mass: Harvard University Press, 2013) at 167 (arguing that reliance on "a group or some organized structure of authority" as a basis of protection of religious freedom excludes "solitary seekers" who have no formal affiliation). 
account cannot. Religious individualism simply does not conform to the practice of many-perhaps most—religious practitioners, past or present. ${ }^{24}$

Moreover, religious individualism cannot fully explain the current state of positive law, whether the statutory recognition of religious institutional authority or the judicial interpretation of the constitutional or statutory text that acknowledges such authority. This shortcoming exists, in part, because the current state of positive law is not the product of, or only of, the sudden revolutionary discovery of religious toleration in the European Enlightenment. It is the result of a gradual development of religious, political, and legal thought that can be traced back to the medieval origins of modern constitutionalism and which the achievements of the Enlightenment came to supplement, rather than supplant. The reduction of the idea of religious liberty to an individualist account both atrophies the Canadian constitutional heritage-depriving it of the intellectual tools to adequately protect religious practice and belief-and necessitates aggressive intervention in so many aspects of social life that it puts other freedoms at risk.

The protection of individual conscience is a great historical achievement, and an institutionalist account of religious freedom does not and should not displace it. But both accounts can and should complement each other. Some controversies will not be completely captured by either concept or may lead to tension between institutions and their adherents, but no more so than now. A clearer conceptual picture might lead us to understand these conflicts better. Perry Dane has written of a "specter of intractability" that haunts the confrontation of law and religion. ${ }^{25}$ If we accept the metaphor, it may not be possible, or desirable, to exorcise this ghost, but we should perhaps seek to gain some insight from its hauntings.

\section{RELIGIOUS INSTITUTIONALISM AND THE CONCEPT OF FREEDOM OF RELIGION}

The current concept of limited government asserts that liberty is achieved when the state abstains from interfering within a sphere of action and belief and leaves

24. For example, Roderick Macdonald has discussed the debates between Thomas More and Martin Luther, early on, and between John Henry Cardinal Newman and Christian evangelicals, much later, regarding the importance of authoritative institutions in religious practice. See Roderick A Macdonald, "Custom Made-For a Non-chirographic Critical Legal Pluralism” (2011) 26:2 CJLS 301 at 310.

25. "Constitutional Law and Religion" in Dennis Patterson, ed, A Companion to Philosophy of Law and Legal Theory, 2nd ed (Chichester, UK: Blackwell, 2010) 119 at 128. 
individuals within that sphere to follow their conscience. But for many religious people, this is not a complete description of religious freedom. While claims of conscience simpliciter may be upheld by a direct appeal to reason, religious practice and belief require affirmative submission to a transcendent external authority. This authority is usually mediated through authoritative religious institutions that are constitutive of, and not incidental to, religious practice and belief. This institutional model of religious freedom is defensible on both conceptual and historical grounds. In this section, we focus mainly on the conceptual argument by interrogating the dominant narratives of religious liberty in liberal thought. We present the historical argument in Part III, below.

Religious liberty is recognized as one of the unqualifiedly positive achievements of modern civilization. It stands at the origin of the foundational narratives of liberalism. But as with all foundational narratives, the prevailing story of freedom of religion in the West is not a straightforward catalog of actions and events, but a morality tale that elevates some aspects of religious liberty and downplays, reinterprets, or excludes others. The individual conscience, religious or not, is the protagonist of this story, while the gradual process of convincing the state to abandon religious establishment and protect the rights of conscience is its plot. It is a plot filled with individual dissenters-Martin Luther at Wittenberg, Miguel Servet in Geneva, Roger Williams in Rhode Island—unfairly persecuted during the Wars of Religion and their aftermath but ultimately triumphant in securing societies where conscience is centrally protected. The most influential contemporary account of liberal thought, John Rawls's theory of justice, adopts this foundational narrative and cements its continuity through the primacy of individual civil and political rights in liberal democracy. In Political Liberalism, Rawls writes:

Thus, the historical origin of political liberalism (and of liberalism more generally) is the Reformation and its aftermath, with the long controversies over religious toleration in the sixteenth and seventeenth centuries. Something like the modern understanding of liberty of conscience and freedom of thought began then. ${ }^{26}$

Rawls is more nuanced in his Lectures on the History of Political Philosophy. ${ }^{27} \mathrm{He}$ identifies three historical roots of liberalism, of which the Protestant Reformation and the Wars of Religion is but one, although perhaps the most important. ${ }^{28}$

26. (New York: Columbia University Press, 1993) at xxiv. See also Ronald Beiner, Civil Religion: A Dialogue in the History of Political Philosophy (New York: Cambridge University Press, 2011) at 283-300.

27. (Cambridge, Mass: Belknap Press, 2007).

28. Ibid at 11 . 
The second, the rise of the middle class and "the establishment of constitutional regimes of limited monarchy," is at least parallel to the Reformation. ${ }^{29}$ The third, "the winning of the working classes to democracy and majority rule," occurred several centuries later. ${ }^{30}$ If the central role of the medieval church in first formulating the legal and political limits to monarchical power is acknowledged, the constitutional foundations of liberalism actually predate the religious strife of the sixteenth and seventeenth centuries by four to twelve hundred years. ${ }^{31}$ And the role of religious societies in organizing tradesmen and workers was evident both in medieval guild life and in nineteenth century syndicalism. ${ }^{32}$ Other Rawlsians, however, have persisted with the prevailing narrative. In Multicultural Citizenship, Will Kymlicka notes that "[1]iberalism and toleration are closely related, both historically and conceptually," given their common origin in the Wars of Religion, but,

[I]f liberalism can indeed be seen as an extension of the principle of religious tolerance, it is important to recognize that religious tolerance in the West has taken a very specific form —namely, the idea of individual freedom of conscience .... There are other forms of toleration which are not liberal. They are based on the idea that each religious group should be free to organize its community as it see fit, including along non-liberal lines. ${ }^{33}$

Elsewhere, Kymlicka dismisses all corporate claims to religious autonomy as illegitimate in a liberal society, unequivocally stating that "the real issue .... is the pre-modern legal doctrine of libertas ecclesiae, which gives religious organizations broad exemptions from equality rights. ${ }^{34}$ By excluding any institutional element from the historical narrative of religious freedom, Kymlicka is able to elide religion and culture and protect religious practices through group-differentiated rights (rights ascribed to individuals by virtue of their membership in a particular group or possession of a kind of status). He thereby denies religious organizations

29. Ibid.

30. Ibid.

31. The dating depends on whether one takes the Investitures Controversy of the eleventh and twelfth centuries as the pivotal moment in Western constitutionalism or whether one reads back to the letters of Hosius of Cordoba in the fourth century or those of Pope Gelasius in the fifth, as we discuss in Part III, below.

32. After all, Pope Leo developed an account of social justice from a defence of religiously affiliated guilds and unions. See Pope Leo XIII, "Rerum Novarum" (15 May 1891) online: Libreria Editrice Vaticana <w2.vatican.va/content/leo-xiii/en/encyclicals/documents/ hf_l-xiii_enc_15051891_rerum-novarum.pdf>.

33. (Oxford: Oxford University Press, 1995) at 155-56.

34. "Disentangling the Debate" in Janice Gross Stein et al, eds, Uneasy Partners: Multiculturalism and Rights in Canada (Waterloo, Ont: Wilfrid Laurier University Press, 2007) 137 at 147. 
any group-rights proper (rights held by the group directly as a person in its own right). ${ }^{35}$ Yet as Sarah Song observes, "[m] ost of Kymlicka's examples [of poly-ethnic rights] involve religious practices." 36

The reduction of religious rights to individual claims for exemption or accommodation has two problematic effects: either it obscures the sources of the claims that individual members of groups make or else it completely ignores the institutional structures that allow for the emergence, development, and protection of religious identities. For instance, consider Jewish kosher or Muslim halal dietary restrictions or even the milder Catholic prohibition on eating meat during the Lenten season. To say that the believer is bound by conscience to abide by the dietary restriction is true, but incomplete. The claim of conscience is not to refrain from eating a certain kind of food, but rather to obey the law and the institutionally designated interpreters of that law-rabbis, imams, or bishops - which in turn specify the dietary practices that believers must follow. The long history of debate and principled (but not secessionist) dissent within religious groups shows that disagreement among religious authorities, or between authorities and believers, need not lead to schism or even disobedience. Continued submission is compatible with principled dissent, especially when religious institutions are not viewed as instrumental but rather as integral to religious faith and practice. ${ }^{37}$ Even schism is hardly ever solitary, nor does it lead to splendid isolation. Most often a division within a religious institution emerges from a disagreement over the boundaries of community or the identity of authority, not whether to have community at all or to do away with authority altogether.

35. Victor M Muñiz-Fraticelli discusses the error of reducing religion to culture. See Victor M Muñiz-Fraticelli, "The Distinctiveness of Religious Liberty" in René Provost, ed, Mapping the Legal Boundaries of Belonging: Religion and Multiculturalism from Israel to Canada (Oxford: Oxford University Press, 2014) ch 5 at 99ff. See also Mary Anne Waldron, Free to Believe: Rethinking Freedom of Conscience and Religion in Canada (Toronto: Toronto University Press, 2013) ch 3 at $54 \mathrm{ff}$. Waldron correctly points out that the confusion of religious freedom with the protection of vulnerable cultural minorities has left religious majorities singularly unprotected, undermining religious freedom as such.

36. Justice, Gender, and the Politics of Multiculturalism (Cambridge: Cambridge University Press, 2007) at 65.

37. Charles Taylor explains that " $[\mathrm{t}]$ his is the connection that consists in the fact that the church is a sacramental communion; some of the force is carried in an expression like 'mystical body." While Taylor has in mind the Catholic corporate conception of the church, a similar constitutive understanding of community pervades other religious traditions. See Charles Taylor, Varieties of Religious Experience Today: William James Revisited (Cambridge, Mass: Harvard University Press, 2002) at 24-25. 
The dominant opinion in both the academy and the courts has tended to equate religious freedom with freedom of conscience, or at least to read the concept of religion expansively to cover beliefs and practices beyond those commonly associated with the historical conception of religion. ${ }^{38}$ The Supreme Court of Canada has done the same, reading the guarantee of "freedom of conscience and religion" in section 2 of the Charter as a term of art, not as the protection of two different things. ${ }^{39}$ This expansive reading, however, has been coupled with a reductive understanding of the proper subject of that freedom and has thus come to conceive of freedom of religion as a normatively protected sphere of thought and action that encompasses the individual man or woman. In this view, any collective practice that is promoted or required by these thoughts and actions can come under the aegis of religious freedom, but only derivatively as necessary to the fulfillment of the discrete individual freedom of the participants.

Where does this leave those religious traditions with very strong institutional components? One suspects that the narrative of liberalism as a tale of the

38. It is beyond the scope of this article to fully examine the vast emerging scholarship on the constitutional protection of conscience (towards which an anonymous reviewer points us). The view that the concept of conscience can sufficiently protect "religious conscience" is becoming the dominant position. See e.g. Schwartzman, supra note 19; Brian Leiter, Why Tolerate Religion? (Princeton, NJ: Princeton University Press, 2012). But this view is contested. Compare Andrew Koppelman, Defending American Religious Neutrality (Cambridge, Mass: Harvard University Press, 2013) ch 4; Timothy Macklem, Independence of Mind (Oxford: Oxford University Press, 2008) ch 3 at 68ff. Waldron likewise endorses a robust defence of religion (distinguishing it, for instance, from protection of minorities on grounds of equality) but ultimately grounds this endorsement on a broader category of conscience and its connection to a democratic society. See Waldron, supra note 35, ch 3 at $54 \mathrm{ff}$, ch 7 at $195 \mathrm{ff}$.

39. One anonymous reviewer considers our claim that the Court has rendered the phrase "conscience and religion" into a term of art is overstatement. However, as we discuss in Part V(A), below, Dickson CJ clearly claimed that section 2(a) of the Charter protects the "single integrated concept of freedom of conscience and religion." See Big M, supra note 7 at para 120. Some lower courts, to their credit, may not be following the Court's signals and have treated the terms "religion" and "conscience" separately. See McAteer et al v Attorney General of Canada, 2013 ONSC 5895, 117 OR (3d) 353; Roach $v$ Canada (Minister of State for Multiculturalism and Citizenship, [1994] 2 FCR 406, 46 ACWS (3d) 387 (both dealing with conscientious objections to swearing allegiance to the Queen in the citizenship ceremony). See also Maurice v Canada (Attorney General) (2002), 210 DLR (4th) 186, 111 ACWS (3d) 472 (FCTD) (dealing with a prisoner's request for vegetarian meals on the basis of conscientious ethical belief). But none of these lower court decisions made it to the Court, and the Court has never issued a single judgment in which it treated freedom of conscience separately. The doctrinal question, in our view, remains open, but only because Dickson CJ's statement should be considered obiter dictum. 
triumphal ascendancy of individual conscience is a distinctly Protestant story, suspicious of ecclesiastical authority over ritual or doctrine. And even then, it is a particularly radical Protestant story associated with the most antinomian elements of the Reformation, which even Martin Luther and John Calvin opposed. It is not that the Protestant tenor of the theory is derived from the personal faith of liberal theorists-religious adherence varies among scholars - but rather that it is inherent to the origins of the narrative itself. Individualism befits a faith that privileges an unmediated relationship to God, a faith of sola fide, sola scriptura, sola gratia ${ }^{40}$ which emerged in reaction to a Roman Catholic Church that taught that grace is received through sacraments administered by ordained priests, that scripture is authoritatively interpreted only by the Magisterium, and that extra Ecclesiam nulla salus. ${ }^{41}$ The medieval order that preceded the Reformation was religiously united but institutionally divided; the world that would emerge from the Wars of Religion would eventually become religiously pluralistic, but politically unitary, at least within each nation-state. Religious freedom would come to be guaranteed not by confrontation between institutions but by moral principles that guide the sovereign's conscience. As the individual religious believer relates directly to God, so the individual religious dissenter confronts the state alone when demanding tolerance and protection. At its highest point, religious individualism grounds a robust defence of the dissenting conscience. At a baser point, it denies recourse to an autonomous institutional religious authority—even to those who wish to submit to it—on the intolerant pretense that adherents have a moral obligation to pursue individual autonomy and that their consciences must be forced to be free.

It is by design that this ecclesiology does not conform to hierarchical religious practices or to institutionalized communal structures. Martin Luther sought to tear down "the 'walls' that stood between the believer and the object of his beliefs": the ecclesiastical hierarchy and the final authority of the Pope over the interpretation of doctrine..$^{42}$ Luther sought a return to the primitive Church, but "his obsession with religious simplicity caused him to ignore the role of religious institutions as political restraints." ${ }^{\text {"3 }}$ Even as many churches that emerged from the Reformation returned to more formal structures of organization, the imprint of Protestant ecclesiology marked the idea of religious

40. "Faith alone, Scripture alone, grace alone."

41. "Outside the Church there is no salvation."

42. Sheldon Wolin, Politics and Vision: Continuity and Innovation in Western Political Thought, revised ed (Princeton, NJ: Princeton University Press, 2004) at 136-39.

43. Ibid at 145 . 
liberty that liberalism eventually inherited and developed. ${ }^{44}$ It is not express antipathy to the institutional aspect of religion that pervades the individualist understanding of religious freedom but rather disbelief that the corporate aspect might be central—not only incidental or instrumental — to religious belief and practice. Charles Taylor observed this of William James, who "has trouble getting beyond a certain individualism." ${ }^{\prime 5}$ Taylor notes that:

Churches are necessary, he clearly concedes. ... What doesn't figure here is the way what one might call the religious connection, the link between the believer and the divine (or whatever), may be essentially mediated by corporate, ecclesial life. ... Then the locus of the relation with God is (also) through the community, and not simply in the individual. But this is the way that the life of the Christian church has been conceived, among many Protestants as well as Catholics; and also the way Israel and the Islamic umma have been conceived. Moreover, this is far from being a thing of the past; this is still the way in which many today understand their religious life. ${ }^{46}$

This is not, however, how many academics understand religious life. Even those who take religion seriously and try to justify the protections afforded to it by the constitutional structure seem to understand religious experience as a kind of self-directed research program and the protection of freedom of religion as a kind of "academic freedom of the soul." Autonomy is the central value and seems to be at odds with authority: "The moral condition demands that we acknowledge responsibility and achieve autonomy wherever and whenever possible." ${ }^{37}$ A conception of freedom of religion that emphasizes only individual autonomy disregards the place of authority in religious discourse.

Perry Dane captures this deficiency by reorienting the justification of religious freedom around the concept of authority. ${ }^{48}$ Authority is indeed central to religion in a way that it is not to conscience. When religious believers, even solitary seekers, make claims for religious exemption, they likely will not say that the general rule from which they seek exemption interfered with their search for ultimate meaning in life. Rather, they will argue that their religious beliefs

44. Because of the lack of a sacerdotal role for Lutheran bishops, Lutheranism is still classified as congregational by some scholars, even though Lutheranism came to embrace a form of episcopacy, especially in Europe.

45. Supra note 37 at 23.

46. Ibid at 23-24.

47. Robert Paul Wolff, In Defense of Anarchism (Oakland, Cal: University of California Press, 1988) at 17.

48. See e.g. “'Omalous' Autonomy” (2004) 2004:5 BYUL Rev 1715 [Dane, “'Omalous' Autonomy"]; Perry Dane, "Religious Exemptions Under the Free Exercise Clause: A Model of Competing Authorities” (1980) 90:2 Yale LJ 350. 
compels them to abide by the directives of an authority — whether directly divine or mediated through temporal intermediaries - to which they have submitted. Submission to this authority is not incidental to religious faith but integral to it. Thus, for governments to reduce the role of religion to that of a system of belief, or even that of belief combined with a narrow range of actions, would be to ignore the behavioural, authoritative, and transcendent elements of religion. Such a course would not merely disadvantage a few sects or individuals but would be a profoundly secularizing act. ${ }^{49}$ By contrast, Dane suggests that:

In the context of adjudicating exemption claims, religion would be defined as a system of belief, not necessarily theistic or institutional, that contained a source of authority perceived to transcend both the believer and the state. This source of authority must be external to personal belief or philosophy, no matter how strong or sincere, and must have a reality and normative force analogous to that of a foreign government. ${ }^{50}$

Dane's approach is remarkably similar to the one suggested by Daniel Weinstock in the Canadian context. Weinstock argues that the exclusive emphasis on subjective belief that has been adopted as a standard by Canadian courts fails to distinguish properly religious claims from claims of conscience. "[T]o the extent that constitutional documents and common philosophical and legal usage distinguish between freedom of religion and freedom of conscience," he urges, "we must find ways to distinguish the moral considerations that underpin them, rather than running them together." ${ }^{51}$ To avoid this elision, he observes that "[a]ll religions provide their members with what might be termed 'authoritative scripts'. That is, they identify certain texts, obligations, beliefs, rites and practices as constitutive of what the tradition is." ${ }^{52}$ Persons seeking protection of their religious freedom, as opposed to their freedom of conscience (which deserves protection under a different category), must make their claims by reference to

49. Ibid at 364 .

50. Ibid at 370 .

51. Daniel Weinstock, "Beyond Objective and Subjective: Assessing the Legitimacy of Religious Claims to Accommodation" (2011) 6:2 Ethics F 155 at 172 [Weinstock, "Beyond Objective"]. Weinstock also recognizes the subjective standard, which runs conscience and religion together, as overly Protestant: "The subjective conception in collapsing religious belief onto conscientious conviction tacitly reduces all religion to what we might call a 'Protestant' conception of religion, which privileges the moment of belief over that of practice and deference to tradition" (ibid at 167).

52. Ibid at 171 . 
the "range of texts, practices, rites ... that are at least partially constitutive of a religion, and a claim has to be made at least partly by reference to these .... ."53

How might an account of religion as an authoritative system support the institutionalist account of religious freedom? If all religious traditions have "authoritative scripts," nearly all of them also have interpreters of those scriptsreligious officials of various sorts. Their role, scope, and authoritativeness vary from one tradition to another, from the congregational minister who is merely a spiritual guide to the Roman Catholic Magisterium whose teachings require the full assent of faith. Nevertheless, even in congregational denominations like the American Lutherans in Hosanna-Tabor, ${ }^{54}$ these interpreters and officials play a distinct religious role that is not always reducible to belief. Likewise, the procedures of church assemblies and tribunals are independent of the beliefs of practitioners in important ways. As Dane observes:

The right to institutional autonomy does not depend, as the right to religion-based exemptions does, on asserting a specific conflict between a secular legal norm and a sincerely held religious belief. To the contrary, the right to autonomy, correctly understood, attaches to a religious institution regardless of its motives and beliefs. ${ }^{55}$

The model of competing authorities that Dane proposes does not predetermine the form such authority will take. But it does distinguish religion, which points to an external basis of authority, from conscience, which considers reasons directly. Dane's model is equally applicable to more or less formalized institutional religious practices, and it does not suggest that religious authority is always hierarchical or excludes the participation of the subject. The Roman Catholic Pope claiming infallibility when speaking ex cathedra and defining doctrine for the entire Catholic Church is, in this sense, the same kind of authority as a Baptist Church assembly that decides on all ecclesiastical and theological matters democratically. As a historical matter, however, the external basis of

53. Ibid at 172 .

54. Supra note 1 at 3 (affirming the "ministerial exemption," a bar to employment discrimination suits by ordained ministers against their church). The closest Canadian parallel to

Hosanna-Tabor is an Ontario Superior Court case where a religious organization was found liable for employment discrimination against a lesbian employee. See Ontario Human Rights Commission v Christian Horizons, 2010 ONSC 2105 at para 106, 102 OR (3d) 267

[Christian Horizons]. The decision acknowledged that, as a religious organization, Christian Horizons was entitled to the statutory exemption but that not participating in same-sex relationships was not a bona fide condition of employment. The employee in question was not a minister, however, and the statutory context of the case makes it significantly different from Hosanna-Tabor.

55. “'Omalous' Autonomy," supra note 48 at 1734. 
authority often has been incarnated in formal institutions and has not merely pointed to an incorporeal divine. This is no accident. Freedom of religion requires the protection of religious institutions since " $[\mathrm{t}]$ he freedom of religion is not only lived and experienced through institutions, it is also protected, nourished, and facilitated by them." ${ }^{56}$ In particular, the Western legal tradition-defined as it is by the periodic confrontation between secular and ecclesiastical power-has underscored the idea of "freedom of the church" as a distinct and intrinsic aspect of religious freedom.

\section{RELIGIOUS INSTITUTIONALISM AND THE HISTORY OF FREEDOM OF RELIGION}

It should be clear by now that the concept of religious freedom in the West is not a theoretical construct, but the outcome of concrete historical development. We contend that this history contains an irreducibly institutional aspect, which is inextricably bound to the meaning of the concept of religious freedom as it has been inscribed in modern constitutional and statutory documents. Tracing this history is relevant to Canadian jurists because the concept of religious freedom recognized in the Constitution Act, 1867 and Constitution Act, 1982 is not merely an abstract proposition but the result of historical development-in the Western legal tradition in general and the English legal tradition in particular. It is important to recognize that this history includes an institutional dimension as well as (and sometimes in tension with) an individualist one. This fact helps make sense of the latitude given to churches and other religious authorities in liberal-democratic states, including Canada, even following widespread secularization. It can also reframe difficult debates in Canadian constitutional law or correct an excessive individualist interpretation of the Charter. ${ }^{57}$

The historical element of religious institutionalism is sometimes referred to as libertas ecclesiae, "the freedom of the church," an idea ultimately traced to the conflict between secular and religious authority that arose at the end of the

Roman Empire and re-emerged in the twelfth century. It was the first statement

56. Richard W Garnett, “The Freedom of the Church': (Towards) An Exposition, Translation, and Defense" (2013) 21 J Contemp Legal Issues 33 at 41. For a forceful development of the structural argument for religious institutionalism, see Horwitz, First Amendment, supra note 18.

57. See generally, Richard W Garnett, "Religious Liberty, Church Autonomy, and the Structure of Freedom" in John Witte Jr \& Frank S Alexander, eds, Christianity and Human Rights: An Introduction (Cambridge: Cambridge University Press, 2010) at 267 at 282. 
of religious freedom in the West and the firmest assertion of the autonomy of religious bodies. As such, it is an integral part of the Western concept of religious liberty. In one of the first important expressions of libertas ecclesiae, the Emperor Constantius sought to pressure and persecute bishops to bring them in line with the theological position that he favoured. "Let my will be like canon among you," he proclaimed, to which Hosius, bishop of Cordova, forcefully responded, "Do not interfere in matters ecclesiastical, nor give us orders on such questions, but learn about them from us. For into your hands God has put the kingdom; the affairs of his Church he has committed to us .... We are not permitted to exercise an earthly rule; and you, Sire, are not authorized to burn incense." ${ }^{\prime 8}$ A century later, Pope Gelasius I replied in the same way to Emperor Anastasius, who had attempted to rearrange the hierarchical order of bishops in the Church. ${ }^{59}$ Gelasius asserted a distinction between two sources of authority that guaranteed autonomy for the religious body: "Two [elements] there are indeed ... by which this world is principally ruled: the consecrated authority of the priests and the royal power," and he called on each to defer to the other in matters of its own competence. ${ }^{60}$

The conflict between temporal and ecclesiastical authorities intensified after the fall of the Empire in the West and came to a head six centuries later. The late-medieval world was by then characterized by many overlapping jurisdictions, of which those of the Pope and the Holy Roman Emperor were the most prominent. Both jurisdictions clashed in the Investiture Conflict, when Pope Gregory VII raised the doctrine of libertas ecclesiae against Holy Roman Emperor Henry IV. ${ }^{61}$ At the heart of the controversy was the Pope's assertion of supreme authority to appoint bishops, a supremacy that the Emperor contested. The conflict was resolved through the Concordat of Worms in $1122 \mathrm{CE}$, which recognized, as a constitutive element of the political order, the existence of the Church as an autonomous authority. ${ }^{62}$ Harold Berman and others have called the principle of libertas ecclesiae one of the foundations of Western constitutionalism

58. Henry Bettenson \& Chris Maunder, Documents of the Christian Church, 4th ed (Oxford: Oxford University Press, 2011) at 20-21.

59. HA Drake, "The Church, Society and Political Power" in Augustine Casiday \& Frederick W Norris, eds, Cambridge History of Christianity, vol 2 (Cambridge: Cambridge University Press, 2007) 403 at 415.

60. Pope Gelasius I, "Letter to the Emperor Anastasius" in Karl F Morrison et al, eds, University of Chicago Readings in Western Civilization: The Church in the Roman Empire, vol 3 (Chicago: University of Chicago Press, 1986) 112 at 112.

61. Brian Tierney, "Religion and Rights: A Medieval Perspective" (1987) 5:1 JL \& Religion 163 at 167.

62. Ernest F Henderson, Select Historical Documents of the Middle Ages (London: George Bell \& Sons, 1892) at 408-409. 
and limited government, as it established external limits to the authority of the emerging state. ${ }^{63}$

The idea of libertas ecclesiae was also central to the development of limited government in England, where a parallel struggle unfolded in the twelfth and thirteenth centuries. In 1164 CE, King Henry II attempted to submit English clerics, and especially ecclesiastical courts, to the authority of the crown by "provid[ing] for appeals from the archbishop's courts to the court of the king," a procedure contrary to canon law. ${ }^{64}$ The King was vigorously opposed by Thomas Becket, the Archbishop of Canterbury, whose martyrdom forced Henry's retreat. ${ }^{65}$ Two kings and half a century later, the freedom of the English Church was asserted again in the first article of Magna Carta, which "confirmed, for Us and our Heirs for ever, that the Church of England shall be free, and shall have all her whole Rights and Liberties inviolable." ${ }^{66}$ The Magna Carta was, of course, especially relevant to the development of institutional religious freedom in Canada: Its first article has never been repealed, and thus it forms part of the received law before Confederation (although, as an ordinary English statute and not part of the Constitution, its current legal force is doubtful).

The Protestant Reformation and Catholic Counter-Reformation accelerated the consolidation of authority in the modern nation-state, but the tension between ecclesiastical and secular authority persisted. ${ }^{67}$ Henry VIII broke with Rome not because of differences of doctrine, but over who should control ecclesiastical institutions. ${ }^{68}$ James VI of England and James I of Scotland struggled to subjugate both the English Church and Presbyterian Church governance in

63. Harold J Berman, Law and Revolution (Cambridge, Mass: Harvard University Press, 1983) at 103-106.

64. Ibid at 257. As Berman observes:

Historians of English law have analyzed the titanic conflict between Henry and Becket largely in terms of their respective positions in regard to article 3 [which restricted the benefit of clergy]. In fact, however, other provisions of the constitutions were more significant. Article 8 would have made the king, rather than the pope, the supreme arbiter of canon law in England.

65. John Hudson, The Oxford History of the Laws of England vol II: 871-1216 (Oxford: Oxford University Press, 2012) at 769.

66. Magna Carta, 1297 (UK), $25 \mathrm{Edw} 1$, c 29, s 1. For various interpretations of the Magna Carta, see Tierney, supra note 61 at 172-74.

67. Harold J Berman, Law and Revolution II: The Impact of the Protestant Reformations on the Western Legal Tradition (Cambridge, Mass: Belknap Press, 2003) at 57; Diarmaid MacCulloch, Reformation: Europe's House Divided, 1490-1700 (New York: Penguin Books, 2003) at 668-79.

68. Erwin Fahlbusch et al, eds, The Encyclopedia of Christianity, vol 5 by Geoffrey W Bromiley (Grand Rapids, Mich: Wm B Eerdmans, 2008) at 614. 
Scotland. ${ }^{69}$ None of these disputes were primarily concerned with the faith of subjects-often the English monarchs made substantial accommodations to belief and practice-but rather with the claims of ecclesiastical institutions to independence from the Crown.

The nineteenth and twentieth centuries finally saw the gradual emancipation of religious minorities in Britain-Protestant dissenters, Roman Catholics, Jews - on the basis of toleration of individual belief, but this proved insufficient to accommodate actual religious practice. ${ }^{70}$ The freedom of the church remained a live controversy and extended even into the established churches in both England and Scotland. ${ }^{71}$ One of the clearest voices raised in defence of religious institutions was that of John Neville Figgis, an Anglican clergyman and historian who took up the defence of the Scottish Kirk - the state-sponsored Presbyterian Church of Scotland - as that body sought to remain free of private patronage and direct state control. ${ }^{72}$ Figgis argued that churches were not the creation of the state. In his view, state intervention in the development of church governance and doctrine was a violence done to the association itself and to the institutions that structured the common life of its members: "The point of issue is not whether Churches can do anything they choose, but whether human law is to regard them as having inherent powers, rights, and wills of their own ... which are inherent and not concessionary." ${ }^{\prime 3}$ In the same period, the celebrated historian Lord Acton

69. Ibid at 614-15.

70. Ian Machin, "British Catholics" in Rainer Liedtke \& Stephan Wendehorst, The Emancipation of Catholics, Jews and Protestants: Minorities and the Nation State in Nineteenth-Century Europe (Manchester: Manchester University Press, 1999) 11; David Cesarani, "British Jews" in Rainer Liedtke \& Stephan Wendehorst, The Emancipation of Catholics, Jews and Protestants: Minorities and the Nation State in Nineteenth-Century Europe (Manchester: Manchester University Press, 1999) 33.

71. Fahlbusch et al, supra note 68.

72. The so-called Free Kirk case is Bannantyne v Overtoun. See Bannantyne v Overtoun (1904), [1904] AC 515 (HL (Scot)). Its effect was felt early on in Canada, and the Supreme Court of Canada cited it as an authority as early as 1906. See Polushie v Zacklynski, [1906] 37 SCR 177, (1906) TLR 152. See also Dobie, supra note 6 (presenting a similar dispute regarding the allocation of assets and government emoluments of the Presbyterian Church after Confederation, which the Privy Council decided primarily on the provincial authority to amend or repeal pre-Confederation statutes). More recently, the British Columbia Court of Appeal has found occasion to discuss the Free Kirk case at length, in the context of property disputes in the Anglican Church. See Bentley $v$ Anglican Synod of the Diocese of New Westminster, 2010 BCCA 506, 62 ETR (3d) 1, leave to appeal to SCC refused, 34045 (16 June 2011) [Bentley]; Rand v The Anglican Synod of the Diocese of British Columbia, 2008 BCCA 294, 84 BCLR (4th) 124.

73. John N Figgis, Churches in the Modern State (London: Longman's Green \& Co, 1913) at 251-52. 
(whose works Figgis edited) echoed these concerns from a Catholic perspective, denouncing the view that individual religious liberty can exist where "religious profession is free, but Church government is controlled." On the contrary, he claimed that "where ecclesiastical authority is restricted, religious liberty is virtually denied." "74

As Figgis and Acton were aware, across the English Channel, the Third French Republic had suppressed all religious orders, allowed only religious associations controlled by laypersons ${ }^{75}$ closed all religious schools ${ }^{76}$ and confiscated church property ${ }^{77}$ which together made it impossible for the Roman Catholic Church to assume a civil form consonant with canon law. The Republic took these actions on the principle that "[ $\mathrm{t}]$ here is no authority but the authority of the Republic." ${ }^{8}$ Led on, in part, by the Papal indictment that "nothing more hostile to the liberty of the Church than this Law could well be conceived," 79 many parishioners ignored the associative structures provided by state law and continued to defer to their bishops, as canon law required of them. After twenty years of acrimony, the state relented on the question of lay control of religious corporations. ${ }^{80}$ As Figgis noted in retrospect, "the persecution was not of religious convictions or practices as such, but of all associations to develop religion in a communal life, on the ground, nominally, that such unions were inimical to the omnipotence of the State." ${ }^{\prime 1}$ The violation of religious liberty that occurred here cannot be

74. John Emerich Edward Dalberg Acton, "The Protestant Theory of Persecution" in John Neville Figgis and Reginald Vere Laurence, eds, The History of Freedom and Other Essays (London: Macmillan, 1906) 130 at 151.

75. Loi du ler juillet 1901 relative au contrat d'association, JO, 1 July 1901, 4025 [Loi des associations].

76. Loi du 7 juillet 1904 interdisant l'enseignement aux congrégations religieuses, 5 July 1904, as repealed by Loi du 3 septembre 1940 abrogeant la loi du 7 juillet 1904 et l'article 14 de la loi du ler juillet 1901, JO, 3 September 1940, 4489-90 [Loi des congrégations].

77. Loi du 9 décembre 1905 concernant la séparation des Eglises et de l'Etat, JO, 11 December 1905, 7205 [Loi de separation].

78. Figgis, supra note 73 at 181, citing Emile Combes, former seminarian and architect of the Loi des congrégations and the Loi de separation. See Guy Laperrière, Les congrégations religious De la France au Québec, 1880-1940, t 2 (Sainte-Foy, Que: Presses de l'Université Laval, 1999) at 55, 569-72.

79. Pope Pius X, "Vehementer Nos" (11 February 1906) at para 9, online: Libreria Editrice Vaticana <w2.vatican.va/content/pius-x/en/encyclicals/documents/hf_p-x_enc_11021906_ vehementer-nos.pdf $>$ [emphasis added].

80. Pope Pius XI, "Maximam gravissimamque" (18 January 1924), online: Libreria Editrice Vaticana <w2.vatican.va/content/pius-xi/en/encyclicals/documents/hf_p-xi_enc_18011924_ maximam-gravissimamque.pdf> (approving proposed state statutes).

81. Figgis, supra note 73 at $24-25$. 
properly explained in individualist terms - it was on individualist terms, in fact, that suppression of the church was justified. It only made sense as a threat to institutional religious freedom, to the integrity of the Church as an institution.

Across the ocean, the evidence for religious institutionalism was mixed, and this was reflected in both private and public law over the following century. Early on, republican sympathies in the United States worked to undermine the independence of religious institutions that did not conform to democratic principles, especially (and recurrently) the Roman Catholic Church. ${ }^{82}$ But soon divisions within churches led to internecine disputes within religious institutions, and courts had to decide whether and how to recognize institutional religious authority in these congregations. From the start, the US Supreme Court refused to rely on substantive tests of religious doctrine, setting aside English precedent that allowed courts to favour doctrinal continuity in settling disputes among congregants. ${ }^{83}$ Instead, the court decided to frame questions of authority in terms of ecclesiastical polity, generally deferring to the central authorities of religious organizations, especially of churches with highly formal administrative and judicial structures. Following this line of cases, courts hesitated when passing judgment on the determinations of ecclesiastical tribunals ${ }^{84}$ or questioning ecclesiastical decisions when they bore on questions of religious faith or discipline. ${ }^{85}$ They refused even to inquire into the alleged arbitrariness of a church's decision to remove a bishop from office. ${ }^{86}$ Such deference helped churches preserve a significant degree of autonomy but also caused problems in

82. One of the earliest examples of this is the trusteeism controversy, which arose in several dioceses of the Roman Catholic Church in the 1820s. See PW Carey, People, Priests, and Prelates (Notre Dame: University of Notre Dame Press, 1987). While academic focus on trusteeism has been on the Baltimore diocese, the controversy spread across the United States and was even felt in Canada. See Terrence Murphy, "Trusteeism in Atlantic Canada: The Struggle for Leadership among the Irish Catholics of Halifax, St. John's, and Saint John, 1780-1850" in Terrence Murphy and Gerald Stortz, eds, Creed and Culture: The Place of English-Speaking Catholics in Canadian Society, 1750-1930 (Montreal: McGill-Queen's University Press, 1993) 126.

83. Watson v Jones, 80 US 679 (1872) [Watson]. Watson was reaffirmed a century later. See Presbyterian Church v Hull Church, 393 US 440 (1969).

84. Gonzalez v Roman Catholic Archbishop of Manila, 280 US 1 (1929).

85. Kedroff $v$ St Nicholas Cathedral, 344 US 94 (1952).

86. Serbian Eastern Orthodox Diocese v Milivojevich, 426 US 696 at 709 (1976). This case was recently cited approvingly by the Supreme Court of Canada. See Mounted Police Association of Ontario v Canada (Attorney General), 2015 SCC 1 at para 64, [2015] 1 SCR 3. 
doctrine and adjudication. ${ }^{87}$ Subsequent jurisprudence allowed lower courts to resolve disputes involving religious organizations solely on the basis of "neutral principles of law," but nonetheless required them to "defer to the resolution of the doctrinal issue by the authoritative ecclesiastical body." ${ }^{88}$ Beyond ecclesiastical disputes-and relevant to present controversies in Canada-the US Court responded to an increasingly pluralistic religious landscape by retrenching protections for religious autonomy, recognizing a fundamental right to private religious schooling, ${ }^{89}$ and accepting as constitutional the exemption of churches from general anti-discrimination legislation..$^{90}$ Over the course of more than a century marked by increasing religious pluralism, some practices were deemed beyond the pale, from polygamy in the nineteenth century ${ }^{91}$ to the ritual ingestion of hallucinogens in the twentieth. ${ }^{92}$ But over the last two decades, institutional religious exemptions have expanded through both federal and state legislation. ${ }^{93}$

Recent US Court jurisprudence suggests renewed deference to the internal authorities and procedures of religious organizations and renewed accommodation of a separate sphere of authority exempt from some general laws, culminating in Hosanna-Tabor. ${ }^{94}$ The decision is remarkable because it goes to great lengths to place the autonomy of religious institutions in a broader Western historical setting, referencing the Magna Carta and the Investitures Controversy. It is also remarkable because it treats religious groups as direct bearers of religious freedom, making repeated reference to "the church," not to parishioners or church leaders, and proscribing interference "with the internal governance of the church, depriving the church of control over the selection of those who will

87. Greenawalt discusses the problems of the hierarchal deference or "polity" approach. See Kent Greenawalt, Religion and the Constitution: Vol I: Free Exercise and Fairness (Princeton, NJ: Princeton University Press, 2009) at 286-89.

88. Jones $v$ Wolf, 443 US 595 at 604 (1979). For the application of the standard by lower courts, see Hassler, supra note 22; Ellis, supra note 22.

89. Pierce $v$ Society of Sisters, 268 US 510 at 519 (1925).

90. Corporation of Presiding Bishop of the Church of Jesus Christ of Latter-day Saints v Amos, 483 US 327 at 15-16 (1987).

91. Reynolds $v$ United States, 98 US 145 at 61 (1878).

92. Employment Division v Smith, 494 US 872 (1990).

93. See e.g. Restoration Act, supra note 2; Land Use Act, supra note 2.

94. Supra note 1. On church autonomy generally, see Kedroff $v$ Saint Nicholas Cathedral, 344 US 94 (1952); Kreshik v Saint Nicholas Cathedral, 363 US 190 (1960); Serbian Orthodox Diocese v Milivojevich, 426 US 696 (1976). On exemptions from discrimination statutes, see Corporatio of Presiding Bishop v Amos, 483 US 327 (1987). 
personify its beliefs." ${ }^{\prime 5}$ Several scholars see Hosanna-Tabor as continuous with an institutional turn, ${ }^{96}$ reflected in disputes as varied as the control of property in cases of schism ${ }^{97}$ and the regulation of businesses whose owners are religiously devout. ${ }^{98}$ There is every reason to think that these recent American cases bear on the minds of the justices of the Supreme Court of Canada and of lower court judges. Regarding internal church disputes (which have remained largely confined to the provincial courts of appeal), judges have struggled to reconcile the influence of American standards of neutrality and separation with the Canadian constitutional context. In property disputes within the Anglican Church, courts have been generally deferential to church hierarchy and institutional autonomy; ${ }^{99}$ in labour disputes between religious employees, the evidence is mixed, but it is still too early to tell. ${ }^{100}$ On broader constitutional terms, Burwell v Hobby Lobby Stores, Inc controversially expanded the range of corporate entities-especially business corporations - able to claim the protection of religious liberty in the United States. ${ }^{101}$ The issue was before the Supreme Court of Canada in Loyola ${ }^{102}$

95. Hosanna-Tabor, supra note 1 at 13 [emphasis added]. The closing line reiterates the ontological point: "The church must be free to choose those who will guide it on its way" (ibid at 22). There is some controversy about the nature of state restraint in this case. The US Supreme Court explicitly refuses to treat the ministerial exception as a jurisdictional bar to intervention in church disputes, but the majority is extremely deferential to a church's own classification of ministers. As Thomas J observes in his concurrence in Hosanna-Tabor, "[T] he Religion Clauses require civil courts to apply the ministerial exception and to defer to a religious organization's good-faith understanding of who qualifies as its minister" (ibid at 1).

96. Horwitz, First Amendment, supra note 18 at 187-89; Ashutosh Bhagwat, "Religious Associations: Hosanna-Tabor and the Instrumental Value of Religious Groups" (2014) 92:1 Wash U L Rev 73 at 108-109.

97. Episcopal Church Cases, 87 Cal Rptr 3d 275 (2009).

98. Burwell, supra note 1.

99. See e.g. Delicata et al v Incorporated Synod of the Diocese of Huron, 2013 ONCA 540 at 69-72, 117 OR (3d) 1 [Delicata], leave to appeal to SCC refused, 35601 (March 4, 2014); Bentley, supra note 73 at 73-76. Both cases involved Anglican parishes that sought to disaffiliate themselves from their diocese over doctrinal differences, arguing a departure by the hierarchy from the original purpose of the religious trust. The Court of Appeal in each case effectively deferred to the hierarchy as to the interpretation of the religious purpose and ruled out unilateral disaffiliation.

100. Christian Horizons, supra note 54. See also Kong v Vancouver Chinese Baptist Church, 2014 BCSC 1424 at paras 49-51, 243 ACWS (3d) 883 [Kong]. The BCSC asserted jurisdiction over a wrongful dismissal suit by Senior Pastor of a church, deeming employment of clergy to be equivalent to any other employment barring explicit clauses subjecting the parties to internal church law.

101. Burwell, supra note 1.

102. Supra note 9. 
and will certainly arise again in the upcoming TWU Law School controversy, as we discuss in Part V(F), below. ${ }^{103}$

\section{RELIGIOUS INSTITUTIONALISM AND CANADIAN CONSTITUTIONAL HISTORY}

Religious institutionalism, we have explained, holds that formal religious institutions have independent claims to religious liberty irreducible to the protection of individual freedom of religion, making it necessary for courts to recognize and give effect to these distinct dimensions of religious freedom. This position is defensible philosophically and persists throughout the history of religious liberty. Yet despite the continuing importance of religion to Canadian constitutional development, the Supreme Court of Canada's jurisprudence is ambiguous about the constitutional protection of the institutional dimensions of religion. Privileging an individualized notion of religious freedom centered on subjective conscience and belief, the Court has incrementally shifted away from older case law that recognized the broader institutional and collective dimensions of religion. ${ }^{104}$ Indeed, this individualistic frame has set the boundaries of analysis in religious freedom litigation and, until very recently, limited the range of possible successful arguments. ${ }^{105}$ As noted by Faisal Bhabha, "the Supreme Court appears to have embraced a definition of religious freedom that has internal conceptual limits which constrain the kinds of claims that will be covered by section 2(a)." ${ }^{106}$ One such internal conceptual limit is the Court's failure to engage meaningfully with religious freedom's institutional dimensions and to afford it its own distinct purpose and function under section 2(a) of the Charter. The overall result is a denatured, decontextualized, and impoverished rendering of religion

103. For further cases on this matter, see infra notes 284-85.

104. See Faisal Bhabha, "From Saumur to L.(S.): Tracing the Theory and Concept of Religious Freedom under Canadian Law” (2012) 58 Sup Ct L Rev (2nd) 109 at 112. Bhabha similarly observes that "the protection of religion within Canadian constitutional jurisprudence has, from its inception, included a dual recognition of both the group and individual bases of religious practice and identity" (ibid at 114).

105. Howard Kislowicz, "Faithful Translations?: Cross-Cultural Communication in Canadian Religious Freedom Litigation" (2014) 52:1 Osgoode Hall LJ 141 at 156-57. As we discuss in Part V(F), below, the Loyola case may indicate a turn.

106. Supra note 104 at 112. 
in Canadian constitutional culture that limits the ways in which the Court may address emerging disputes concerning religious organizations. ${ }^{107}$

A discussion on the origins of the constitutional protection of religious freedom in Canada must inevitably begin with an overview of colonial history. Canada's religious heritage developed to ensure the coexistence and protection of its Protestant and Roman Catholic inhabitants, reflecting the country's roots in the French and British empires. Indeed, even prior to Confederation, the protection of religious freedom was central in maintaining social peace and national cohesion. ${ }^{108}$ The Articles of Capitulation of $1760,{ }^{109}$ the Treaty of Paris, ${ }^{110}$ the Royal Proclamation, 1763, ${ }^{111}$ and the Quebec Act of $1774^{112}$ all contain special provisions protecting against restrictions on the exercise of religion. ${ }^{113}$ The Quebec Act of 1774 is perhaps the most important of these foundational documents. As a socio-political instrument enacted by the Parliament of Westminster to secure the French population's neutrality in conflicts with the Thirteen Colonies, ${ }^{114}$ the Québec Act contained specific provisions securing the institutional status of the Roman Catholic Church, which had enjoyed limited protection under the common law. For instance, section 5 declared and enshrined the free exercise of Roman Catholicism in the province of Quebec, subject only to "the King's supremacy." 115 In turn, this protection was maintained in several additional documents. This was not quite a blanket approval of religious institutionalism, but it did constitute the recognition that some religious practice was intrinsically tied to concrete authoritative institutions. To that effect, section 42 of the Constitution Act, 1791 provided that any law relating to or affecting "the

107. For an analysis of Canadian constitutional culture's conceptualization of religious freedom, see Benjamin L Berger, "Law’s Religion: Rendering Culture" (2007) 45:2 Osgoode Hall LJ 277 [Berger, "Law's Religion”].

108. See e.g. Benjamin L Berger, "Religious Diversity, Education, and the 'Crisis' in State Neutrality" (2014) 29:1 CJLS 103 at 104 [Berger, "Religious Diversity"].

109. "Articles of Capitulation," in A Collection of the Acts Passed in the Parliament of Great Britain and of Other Public Acts Relative to Canada (Quebec: PE Desbarats, 1824) 2, arts 27, 30, 40, 47 .

110. Definitive Treaty of Peace Between Great Britain and the United States of America, United States, France, Great Britain, and Spain, 10 February 1763, 42 Cons TS 279 [Treaty of Paris].

111. RSC 1985, App II, No 1 [Royal Proclamation].

112. An Act for Making More Effectual Provision for the Government of Québec in North America, 1774, 14 Geo III, c 83 [Quebec Act].

113. This is confirmed by Rand $\mathrm{J}$ in $R v$ Robertson and Rosetanni. See $R v$ Robertson and Rosetanni, [1963] SCR 651, 41 DLR (2d) 485 [Robertson cited to SCR].

114. Sir Reginald Coupland, The Québec Act: A Study in Statesmanship (Oxford: Oxford University Press, 1925) at 208-17.

115. Quebec Act, supra note 112, ss 5, 15. 
enjoyment or exercise of any religious form or mode or worship" "116 would only take effect upon passage by both Houses of Parliament followed by Royal Assent. Section 42 was further carried over in the Act of Union of $1840,{ }^{117}$ which established the Province of Canada. ${ }^{118}$ Another key example is the Statute of $1852,{ }^{119}$ which affirmed "legal equality amongst all Religious Denominations" and declared it "an admitted principle of Colonial Legislation" and "a fundamental principle of [the Canadian] civil polity."

From as early as 1760, then, Canadian constitutional culture distilled the concept of religious freedom into two identifiable strains. ${ }^{121}$ The first grounds religious freedom on the "complete liberty of religious thought" in which "the conscience of each is a personal matter and the concern of nobody else." 122 This is consistent with an individualistic conception of religious freedom. The second strain is distinctly institutional. Emphasizing the collective and institutional dimensions of religious practice, it conceives religious freedom as extending beyond attributes exclusive to the individual rights-bearer. The pre-Confederation treatment of religion's institutional dimensions is best summarized by Justice Rand in Robertson, who observed:

$[R]$ eligious freedom has, in our legal system, been recognized as a principle of fundamental character; and although we have nothing in the nature of an established church ... it is unquestionable ... that the untrammeled affirmations of religious belief and its propagation, personal or institutional, remain as of the greatest constitutional significance throughout the Dominion. ${ }^{123}$

Confederation largely preserved the protection conferred on both individual and institutional religious freedom in the colonial era. ${ }^{124}$ For instance, section 129 of the British North America Act, 1867 continued all the laws enacted before it, subject to each legislature's prerogative to repeal, abolish, or alter them. ${ }^{125}$ This ensured that the existing legal protections of religious freedom remained in

116. (UK), 31 Geo III, c 31, s 42.

117. British North America Act, 1840, 3-4 Vict, c 35, reprinted in RSC 1985, App II, No 4 [Act of Union].

118. Ibid.

119. Statute of 1852 of Old Province of Canada (UK), 14 \& 15 Vict, c 175 [Statute of 1852].

120. Ibid.

121. Robertson, supra note 113 at 655.

122. Chaput v Romain, [1955] SCR 834 at 840, 1 DLR (2d) 241 [Chaput]. See also Lamb v Benoit, [1959] SCR 321 at 323, 17 DLR (2d) 369.

123. Robertson, supra note 113 at 655 [emphasis added].

124. Walter v Attorney General of Alberta, [1969] SCR 383 at 391-92, 3 DLR (3d) 1.

125. (UK) $30 \& 31$ Vict, c 3, s 129, reprinted in RSC 1985, App II, No 5

[Constitution Act, 1867]. 
force after Confederation. In addition, and as a political compromise of central importance, ${ }^{126}$ section 93 extended protection to Protestant and Roman Catholic dissentient schools, whose "Powers, Privileges, and Duties" were to remain unaffected by the birth of the Canadian nation-state. ${ }^{127}$

Additional jurisprudence demonstrates the Supreme Court of Canada's respect for, and deference to, religious institutions in the post-Confederation era. For example, in Ash v Methodist Church, ${ }^{128}$ the Court declined to exercise jurisdiction over an application for mandamus for reinstatement by a plaintiff who had been prevented from pursuing his calling as a Minister of the Church. Consistent with the "ministerial exception" doctrine, former Chief Justice of Canada Strong held that " $[t]$ he question whether a minister is unacceptable or inefficient is peculiarly one for the judgment of the Conference." Correspondingly, courts of law do not have the right to interfere in internal religious matters. ${ }^{129}$ Indeed, the prerogative of religious institutions to self-determine, in matters including membership and

126. See e.g. Berger, "Religious Diversity," supra note 108 at 104.

127. Constitution Act, 1867, supra note 125, s 93. See e.g. Reference re Education Act (Que),

[1993] 2 SCR 511 at 529, 154 NR 1. However, in 1997, Quebec exercised its unilateral constitutional amendment powers under s 45 of the Constitution Act, 1982 to effectively render s 93 inapplicable in the province. See Constitution Act, 1867, supra note 125, s 93A, as amended by Constitution Amendment, 1997 (Quebec), SI/97-141, (1998) C Gaz II, 308. However, this amendment should not preclude religious institutions, educational or otherwise, from invoking the protection of section 2(a) of the Charter to advance institutionalist claims against state interference. The accommodation to religious educational institutions was a narrow protection designed to secure equal public funding and preclude suppression—creating, in effect, a "quasi-establishment." See MH Ogilvie, "What is a Church by Law Established?” (1990) 28:1 Osgoode Hall LJ 179. But religious establishment is wholly separate from (and sometimes contrary to) the broader principle of "freedom of the church" as we discuss in Part V, below. See infra note 160. Moreover, on more specific constitutional grounds, a province's unilateral amendment of $s 93$ cannot be equated with an amendment to the Charter, which would require the consent of seven provinces representing at least 50 per cent of the Canadian population, as constitutionally required. See Procedure for Amending Constitution of Canada, ss 38(1), 42, being Part V of the Constitution Act, 1982, being Schedule B to the Canada Act, 1982 (UK), 1982, c 11. Furthermore, a provision of the Canadian constitution cannot be read as interfering with rights protected by another. See e.g. Adler v Ontario (Attorney General), [1996] 3 SCR 609 at 643-44, 30 OR (3d) 642 [Adler]. Thus, the amendment of a constitutional provision should not be understood as amending another constitutional provision addressing cognate matters. This is particularly true since "[t]he Canadian Charter does not repeal the Constitution Act, 1867 or the constitutional compromises it reflects." See Quebec (Commission des droits de la personne et des droits de la jeunesse) v Communauté urbaine de Montréal, 2004 SCC 30 at para 16, [2004] 1 SCR 789.

128. [1901] 31 SCR 497, 22 Occ N 3 [Ash].

129. Ibid at 498 . 
ascendancy to higher positions in the church hierarchy, lies at the core of religious institutionalism. The decision in Ash unambiguously reflects this principle.

Both pre- and post-Confederation jurisprudence therefore shows that the Court was receptive to a dual conception of religious freedom. Religious bodies were regarded as major institutions of social control, ${ }^{130}$ entitled to respect and deference from the State in matters solely within their purview. This is consistent with the notion of libertas ecclesiae and the state's recognition of a sovereign independent of its own. The tendency seems to have maintained itself following the enactment of the Canadian Bill of Rights, ${ }^{131}$ Canada's first federal instrument providing for the protection of fundamental rights and freedoms.

Enacted in 1960 by the Parliament of Canada, the Bill of Rights was the first step in Canada's federal human rights protection policy. ${ }^{132}$ Although the Bill of Rights is an ordinary rather than constitutional enactment, and although it only applies to matters within federal jurisdiction, ${ }^{133}$ it provides robust protection to religious freedom. Section 1(c) reads: "It is hereby recognized and declared that in Canada there have existed and shall continue to exist without discrimination by reason of race, national origin, colour, religion or sex, the following human rights and fundamental freedoms, namely ... [f] reedom of religion." 134 A plain language interpretation of the Bill of Rights reveals section 1 as playing two distinct, interlinked functions. First, the Bill of Rights recognizes the continued existence of the fundamental freedom of religious liberty without discrimination. Second, the Bill of Rights plays a declaratory function, enshrining the conception of religious freedom that existed and continued to exist as of the Bill of Rights's enactment. Both guarantees of religious freedom found under section 1(c) mirror the protection conferred under the Statute of $1852^{135}$ and reiterated in Chaput..$^{136}$

130. Bhabha observes that individual religious freedom in pre-Confederation Canada "appear[s] to be derived from the acknowledgement and affirmation of religion as a legitimate moral and institutional player with status and interests." See Bhabha, supra note 104 at 114.

131. SC 1960, c 44 [Bill of Rights].

132. See generally William A Schabas, International Human Rights Law and The Canadian Charter, 2nd ed (Scarborough, Ont: Carswell, 1996) at 6-8. While the Bill of Rights was the first federal protection of civil liberties, "[s]ince the latter part of the second world war, Canadian provincial Legislatures have been active in promoting egalitarian civil liberties by statute." See Peter Hogg, Constitutional Law of Canada, 5th ed (Toronto: Thompson Reuters, 2007) ch 34.3(a) at 34-37. We thank an anonymous reviewer for pointing out the provincial precedent.

133. Bill of Rights, supra note 131, s 5(3).

134. Ibid, s 1 (c).

135. Statute of 1852, supra note 119.

136. Chaput, supra note 122. 
An important aspect of section 1 of the Bill of Rights is the distinction between fundamental freedoms and human rights. Of the six protections enumerated in section 1, the first two are named "human rights," which are held by "the individual." For example, section 1(a) protects "the right of the individual to life, liberty ... [and] security of the person." ${ }^{137}$ The next four are called "freedoms" and are listed without reference to the nature of the rights-holder. One way of understanding the distinction is that fundamental freedoms extend beyond individual human beings and may protect collective or corporate persons directly, while human rights attach only to natural persons. To be sure, the Bill of Rights categorizes religious freedom as a "fundamental freedom," without particular reference as to the natural or legal persons that may invoke the guarantee. The fact that these individual rights are associated with the human person would suggest that the "freedoms" are not so limited. The same was at least recognized in Robertson, ${ }^{138}$ the first case to examine religious freedom under the Bill of Rights. Specifying the scope, extent, and effect of section 1(c), Justice Ritchie noted that:

The Canadian Bill of Rights was not concerned with "human rights and fundamental freedoms" in any abstract sense, but rather with such "rights and freedoms" as they existed in Canada immediately before the statute was enacted ... . It is therefore the "religious freedom" then existing that is safe-guarded by the [Bill of Rights's] provisions. $^{139}$

Importantly, Justice Ritchie outlined an explicitly dualistic conception of religious freedom existing at, and continuing to exist as of, the enactment of the Bill of Rights. Emphasizing the importance of understanding this concept as it was recognized before the Bill of Rights, Justice Ritchie first highlighted the individual dimensions of religious freedom. Yet, Justice Ritchie also accepted that "'religious belief' and its propagation, personal or institutional," as they existed from the British Conquest onwards, remained "of the greatest constitutional significance." 140

Judicial reluctance to interfere in internal church disputes-as prominently exemplified in Ash - also continued in the post-Bill of Rights era. For example, in Hofer $v$ Hofer and Interlake Colony of Hutterian Brethren, the Court rejected

137. Bill of Rights, supra note 131, s 1(a).

138. Robertson, supra note 113. Analytically, the distinction seems arbitrary, as some rights, such as the right to the enjoyment of property, can attach to legal persons such as corporations. Therefore, it may be taken merely as a hypothesis about the contemporary historical meaning of the Bill of Rights.

139. Ibid at 654 .

140. Ibid at 655 [emphasis added], citing Saumur v City of Quebec, [1953] 2 SCR 299 at 327, 106 CCC 289 [Saumur]. 
an action for declaratory judgment brought by excommunicated members of the Lakeside Colony of Hutterian Brethren. ${ }^{141}$ In a six-to-one decision, the Court declined to intervene in matters of internal Church membership and refused to order the distribution of the Colony's assets to the plaintiffs and community members. The overall result, expressed in Justice Richie's majority opinion, is an unmistakable nod to religious institutionalism. ${ }^{142}$ The fact that the case was not brought under the Bill of Rights does not disrupt this conclusion. If anything, decisions such as Interlake demonstrate that the protection of religious institutionalism can take various forms, whether constitutional, legislative, or by virtue of judicial policy. Taking these developments in their totality, the dualistic strain of religious freedom clearly continued to exist following the Bill of Right's enactment. In fact, the Bill of Rights's endorsement of this dualistic conception makes it difficult to comprehend the shift to a purely individualistic conception of religious freedom that followed the enactment of the Charter. ${ }^{143}$

\section{RELIGIOUS INSTITUTIONALISM IN THE POST-CHARTER ERA}

The enactment of the Charter in 1982 inaugurated a new period in the protection of religious freedom in Canada. Section 2(a) declares that everyone has the fundamental freedom that is "freedom of conscience and religion." ${ }^{44}$ Expressed in such broad and general terms, the constitutional guarantee of religious freedom under section 2(a) has been decisively shaped by the Supreme Court of Canada's understanding of the Charter as a constitutional instrument and of freedom of religion as a historical and conceptual category.

141. [1970] SCR 958, 13 DLR (3d) 1 [Interlake cited to SCR].

142. There was, to be sure, disagreement over the nature of the colony. Richie J, writing for the majority, did not distinguish between the church and the colony, as the latter, while a business with a separate legal existence, was animated by the same religious principles. See Interlake, ibid at 968-69). Cartwright J and Spence J did not take the Hutterite church's self-understanding as determinative and saw the controversy over the colony's assets as a contractual dispute (ibid at 961-63).

143. In a post-Charter decision, the Court followed the majority in Interlake in acknowledging the Church's internal legal authority—extending to its tradition as source of law—all the while demanding that it adhere to principles of natural justice, such as notice and process. See Hutterite Brethren of Lakeside Colony v Hofer, [1992] 3 SCR 165, 97 DLR (4th) 17. For a full discussion of the history of Hutterite disputes, see Alvin J Esau, The Courts and the Colonies: The Litigation of Hutterite Church Disputes (Vancouver: University of British Columbia Press, 2004) at 1-12.

144. Charter, supra note 5, s 2(a). 


\section{A. BIG M AND THE INDIVIDUALIZATION OF RELIGION}

The process began with the landmark case of Big M Drug Mart, ${ }^{145}$ which set the tone for later jurisprudence. The facts of Big $M$ are well known: The owners of the namesake grocery store had been accused of selling merchandise on Sunday in violation of the Lord's Day Act. The Lord's Day Act had previously been found to be constitutional in the Robertson case, but that decision dated to a legal regime governed by the Bill of Rights. By the time the Big $M$ case made its way to the Court, the Charter had been enacted. The Court, reversing its prior decision in Robertson, declared the Lord's Day Act in violation of the Charter and thus unconstitutional. This legal change reflected broader changes in Canadian society, especially simultaneous tendencies towards secularization and greater religious pluralism, which had important consequences in the Court's approach.

The Court in Big $M$ understood the Charter as a constitutional break. Interpretation of rights and freedoms under the Bill of Rights was not determinative in interpreting their Charter homologues. For Chief Justice Dickson, the crucial variable was the imperative nature of the language used in the Charter: Whereas the Bill of Rights's language purports to "simply 'recognize and declare" rights existing at the time of its enactment, the Charter proclaims that everyone has the rights and freedoms it guarantees. ${ }^{146}$ This limits the utility of citing pre-Charter jurisprudence. ${ }^{147}$ Particularly, Chief Justice Dickson singled out Robertson as being of no application in the post-Charter era. The definition of religious freedom spelled out in that case, which recognized both individual and institutional dimensions, ${ }^{148}$ was said to be particular to the Bill of Rights. However, even if the Bill of Rights only recognized existing rights, while the Charter declares a new rights regime, it does not follow that the Charter abrogates rights already recognized under the previous instrument. ${ }^{149}$ The usual reading of Big $M$ is that in cases where a right is protected under the Bill of Rights and the Charter, the latter supersedes the interpretation of the right under the former; Charter rights are generally broader and thus "the cautious, restrictive interpretations of the Bill of Rights are more likely to be repudiated in favour of a generous interpretation

145. Supra note 7

146. Ibid at para 115 .

147. Ibid.

148. Robertson, supra note 113; Saumur, supra note 140.

149. This is recognized explicitly for the provisions of the Bill of Rights that are not themselves contained in the Charter, namely the protection of due process (and through it, property rights) in section 1 (a) and the guarantee of a fair hearing for the determination of rights and obligations in section 2(e). See Hogg, supra note 132, ch 35.1, 35-2. 
of Charter rights." ${ }^{150}$ Therefore, the supersession of Robertson's interpretation of religious freedom should be understood as an expansion, not a displacement.

The constitutional break that the Charter effected allowed the Court to re-ground the concept of religious freedom on individualist foundations, ignoring its institutional foundations. While Chief Justice Dickson emphasized the importance of religious freedom's historical context, he asserted that "the origins of the demand for freedom of religion are to be found in the religious struggles of post-Reformation Europe." ${ }^{151}$ Big $M$ stands as a reflection of the Reformation's individualization of religion since it emphasized the centrality of individual conscience and "the inappropriateness of governmental intervention to compel or constrain its manifestation." 152 As a historiography of religious freedom, this reflection is factually incorrect (as our earlier historical discussion illustrates) but also reductionist and constitutionally problematic. To an extent, this move followed directly from an individualist reading of the Reformation. Notions of libertas ecclesia and the English institution of an established church are not examples congenial to disestablishment; the explosion of denominational diversity evoked by the Reformation may seem more apt. But it is also dismissive of the ways in which institutional concerns are constitutive of religious practice and belief for many people, not only Christians. ${ }^{153}$ The passing on of tradition through private religious education, the performance of ritual and organized worship, the discharging of moral duties and procurement of mutual aid through religious charities, and even the submission to religious authority are not exclusive to Christianity, are not dependent on religious establishment, and are not intelligible as a mere aggregation of individual preferences. In deriving religious freedom from a peculiar reading of the Protestant experience, the Court in effect embedded a sectarian concept of religion into the Charter, one derived

150. Ibid, ch 35.5, 35-12.

151. Big $M$, supra note 7 at para 118.

152. Ibid at para 121.

153. Of course, as the most cursory reading of European history after the Peace of Westphalia shows, it is historically inaccurate to identify the Reformation with disestablishment. This is not what Dickson CJ does, however, using the Reformations instead to invoke a flowering of diversity. 
from a highly intellectualized Enlightenment Protestantism that is not especially widespread among contemporary religious adherents. ${ }^{154}$

This historiography provides a further reason for the conceptual integration of religious freedom and freedom of conscience into a single unitary conception under the Charter. "It is from these antecedents," Chief Justice Dickson writes, "that the concepts of freedom of religion and freedom of conscience became associated, to form, as they do in s 2(a) of our Charter, the single integrated concept of 'freedom of conscience and religion.'”155 The integration of these two distinct concepts subordinates the enjoyment and benefit of religious freedom under the Charter to the ability to hold conscientious belief. ${ }^{156}$ The singular and unitary conception of religious freedom and conscience also introduced an air of redundancy to section $2(a)$, essentially obscuring the need for an independent understanding of freedom of conscience. As noted by Howard Kislowicz, Richard Haigh, and Adrienne $\mathrm{Ng}$, the inclusion of conscience under section $2(a)$ "is not an elegant variation of religion," but should rather be seen "an independent freedom" essential to "giv[ing] the Charter's terms full meaning." 157 For Kislowicz, Haigh, and Ng, “'[c]onscience,' as an independent freedom, may

154. It is a good question, to our knowledge not directly addressed by the case law, whether the different effect of religious individualism on different church structures could give rise to a s 15 claim of "equal protection and equal benefit of the law." See Charter, supra note 5, s 15(1). The issue has been briefly addressed by the US Supreme Court. See Mitchell v Helms, 530 US 793 (2000) (a plurality opinion that deemed that a judicial test for classifying religious schools discriminated against Roman Catholic schools). But Supreme Court of Canada jurisprudence makes it difficult to draw analogies to Canadian law. See Adler, supra note 127.

155. Big $M$, supra note 7 at 361 . We find it peculiar that post-Reformation Europe rather than post-Reformation Britain is the chosen historical antecedent for religious freedom under the Charter.

156. There is scant evidence in either direction of the reading of $s 2$ intended by the drafters, but there are strong indicia that the Charter did not intend to equate religion and conscience in this way. First, the term "conscience" makes a new appearance in the Charter, whereas it does not appear in the Bill of Rights (which protected only freedom of religion) or in the US Constitution (which was a source of inspiration for the Charter and is still used today in its interpretation for comparative effect). Second, we have first-hand testimony from Jean Chrétien who, while Minister of Justice, negotiated the Charter and recalls in his memoirs that Pierre Trudeau seemed committed to the dual language despite reluctance from the provincial governments. See Jean Chrétien, Straight from the Heart (Toronto: Key Porter Books, 1994) at 173. So we are left with the distinct impression that conscience and religion were intended to mean different things in the Charter, although the subject merits a more detailed discussion of the principles of statutory interpretation than is possible here.

157. "Calculations of Conscience: The Costs and Benefits of Religious and Conscientious Freedom” (2011) 48:3 Alta L Rev 679 at 707. 
[even] help bring back the very point of having religion and religious freedom." ${ }^{158}$ The conception espoused by Chief Justice Dickson is furthermore at odds with the recognition of non-natural persons' capacity to enjoy the protection of other fundamental freedoms, such as freedom of expression and freedom of association.

As Benjamin Berger argues, in cases like Big $M$, "the dominant theme ... was the disembedding of Christian privilege. ... [F] reedom of religion was really about evenhandedness among religious and non-religious creeds, freedom from state-enforced religious practices or norms, and, in particular, disrupting the structural hegemony of Christianity." 159 But rather than extend individual and institutional religious protection to all creeds and consciences, the Court reduced all religious experience to individual belief, ignoring the pressing institutional claims of these now (only partially) protected religious systems. ${ }^{160}$

\section{B. EDWARDS, HY \& ZEL'S, AND THE RELIGIOUS LIBERTY OF THE CORPORATION}

Big $M$ is also the source of confusing Supreme Court of Canada jurisprudence on the religious liberties of corporations. Although the case involved a corporate

158. Ibid at 713 .

159. Berger, "Religious Diversity," supra note 108 at 109.

160. The extension of religious freedom, albeit in a reduced individualist form, to non-Christian creeds and conscientious believers appears to sit uncomfortably with the Supreme Court of Canada's decision in Adler, where the Court found that state support for Roman Catholic schools in Ontario-guaranteed under the Constitution Act, 1867-did not have to be extended to other religious denominations under Charter principles of religious freedom or equality. But the case is in every way the exception that proves the rule. Support for certain minority religious schools, the Court explained, "is the product of a historical compromise which was a crucial step along the road leading to Confederation." Because s 93 "forms a comprehensive code with respect to denominational school rights," it cannot be enlarged through the operation of s 2(a) of the Charter. Section 93 does not represent a guarantee of fundamental freedoms; it only entrenches "certain rights ... which were enjoyed at the time of Confederation." See Adler, supra note 127 at paras 29, 35. The 1867 provision implicitly acknowledges the importance of institutions in the life of a religious community (in this case the Roman Catholic community in Ontario and the Protestant communities in Quebec) and therefore supports our argument that religious institutionalism has always been a part of Canadian constitutional history. Yet the religious institutionalist claim does not depend on a claim to religious establishment. While a full explanation is outside the scope of this article, it should suffice to recall — from the historical account in the first section - that Hosius of Cordova wrote against the temporal encroachment on the authority of bishops before Theodosius's edict, Cunctos Populous, made Nicene Christianity the official religion of the Empire in $380 \mathrm{CE}$; Pope Gelasius made identical statements afterwards. See Bettenson, supra note 58 at 31 . Figgis also suggested that church autonomy may indeed be compromised by religious establishment. See Figgis, supra note 73 at 8. 
legal person challenging the constitutionality of a law on the grounds of religious freedom, the Court did not conclusively determine whether a corporation-a religious corporation or a corporation simpliciter - could enjoy the protection conferred under section 2(a). Rather, according to Chief Justice Dickson:

Whether a corporation can enjoy or exercise freedom of religion is ... irrelevant. ... [I] $\mathrm{f}$ the law impairs freedom of religion it does not matter whether the company can possess religious belief. ... A law which itself infringes religious freedom is, by that reason alone, inconsistent with $\mathrm{s} 2(a) \ldots$ and it matters not whether the [claimant] is ... an individual or a corporation. ${ }^{161}$

Following this rationale, constitutional invalidity would be premised not on whether the corporation's or institution's rights had been violated, but simply on whether the impugned restriction on religious freedom is compatible with section $2(a)$. Yet even if it were contended that this represents a way of protecting religious institutionalism, it does so in a circuitous way that fails to account for the distinctive nature of religious freedom's institutional dimensions. The emphasis on the corporate form does not distinguish between the rights of religious institutions and the religious rights of business entities (including corporations) — categories that inevitably overlap in particular cases yet are distinct in purpose, scope, and ontological significance.

$R v$ Edwards Books and Art Ltd paid further attention to whether legal persons may invoke the guarantee of religious freedom. ${ }^{162}$ As an unofficial sequel to Big M, Edwards centered on a challenge to the Retail Business Holidays Act, the secular statute enacted following the Court's invalidation of the Lord's Day Act in Big M. However, the issue that attracts our attention is whether Edwards Books Ltd. could benefit from section 2(a). Chief Justice Dickson specified that he had "no hesitation in remarking that a business corporation cannot possess religious beliefs." 163 Without undertaking a comprehensive analysis of the above proposition, suffice it to say that Chief Justice Dickson's statement is not conclusive on the issue of whether a religious corporation or institution may invoke and benefit from the protection found under section 2(a). Indeed, the question of whether a business corporation may invoke the guarantee is quite different from the question of whether an institution or body, whether incorporated or unincorporated and existing solely for religious purposes, may invoke section 2(a). In this sense, it is possible to differentiate two categories of beneficiaries of religious institutionalism. Religious institutions qua religious institutions such

161. Big $M$, supra note 7 at paras $40-41$.

162. [1986] 2 SCR 713, 45 DLR (4th) 1 [Edwards cited to SCR].

163. Ibid at 784 . 
as churches and synagogues constitute the primary beneficiaries. The secondary, and admittedly more doubtful, beneficiaries are corporate entities whose claims to religious freedom, while less evident, theoretically could be demonstrated in appropriate circumstances. ${ }^{164}$

The problem was highlighted in the case of $H y$ and Zel's Inc $v$ Ontario (Attorney General). ${ }^{165}$ The claimants, commercial businesses owned by adherents of the Jewish faith, had been convicted of breaching the Retail Business Holidays Act but contested the statute's constitutionality on religious freedom grounds. A key question was whether corporations have standing to seek a declaration of unconstitutionality. The majority proceeded on the assumption that the combined effect of Big $M$ and Edwards had conclusively determined that corporations could not invoke the section 2(a) guarantee of religious freedom. Nevertheless, for the purpose of analysis, the majority assumed that corporations may hold religious rights but decided that the corporations did not have standing because there was no evidence or allegation that their rights were violated. ${ }^{166}$ Thus, in the absence of evidence of a violation, standing could not be granted, and the question of whether the corporation could in fact invoke section 2(a) did not need to be revisited. ${ }^{167}$

The dissenting opinion, written by Justice L'Heureux-Dubé, directly attacked the majority's treatment of corporate religious rights. ${ }^{168}$ The dissent rejected the argument that the issue of corporate religious rights had been conclusively determined. For Justice L'Heureux-Dubé, Big M

164. The view that a commercial business corporation is presumptively unable to claim the protection of religious freedom in its own name is consistent with the Supreme Court of Canada decision in Pollack. See Pollack v Comité Paritaire du Commerce de Détail à Québec, [1946] SCR 343 at 347, 2 DLR 801. The case pre-dates the Charter, but in it the Court held: "L'appelante étant une corporation commerciale, ne peut professer une religion ni lui appartenir." This translates as: "The appellant being a commercial corporation, it can neither profess nor belong to a religion."

165. [1993] 3 SCR 675, 107 DLR (4th) 634 [Hy and Zel's cited to SCR].

166. Ibid at 693.

167. The restriction on standing proved controversial. In Big $M$, the corporation that sought to declare the Lord's Day Act unconstitutional was a defendant in a criminal case, while in $H y$ \& Zel's, the corporation was a plaintiff in a civil action challenging the legislation under which it was being prosecuted. The different outcome was significantly determined by the Court's restriction of public interest standing rules after $\operatorname{Big} M$, a limitation that was widely criticized for being unnecessary and inefficient. See June M Ross, "Standing in Charter Declaratory Actions" (1995) 33:1 Osgoode Hall LJ 151; Hogg, supra note 132, ch 59.2(d)-(e), 59-3-6. We will nonetheless focus on the issue of institutional religious rights, which was a matter of dispute between the majority and the dissent.

168. Hy and Zel's, supra note 165 at 680. 
did not decide that a corporation cannot invoke the rights guaranteed under s. 2(a) of the Charter ... . Rather, the ratio of that case is the positive right of a corporation to rely on the Charter rights of others in defence to a criminal charge. The Court did not consider at all whether corporations may have rights under s. 2(a) of the Charter: it was held to be irrelevant, in view of the fact that no one could be convicted under an unconstitutional law, be it a corporation or an individual litigant. ${ }^{169}$

The effect of Edwards was also highlighted. The dissent read the case as supporting the argument that corporate religious rights under the Charter have yet to be resolved. Justice L'Heureux-Dubé reminded the majority that that case had rejected only the invocation of section $2(a)$ for "business corporations." ${ }^{170}$ The issue of whether a religious corporation may invoke the section 2(a) guarantee was therefore unresolved and in pressing need of clarification. Nevertheless, the $H y$ and Zel's case forecasted two elements central to understanding any claim revolving on religion's institutional dimensions. First, Hy and Zel's did not extinguish the argument for corporate religious rights under the Charter; rather, in avoiding the question, the Court preserved the latent ambiguity created in Big $M$ and Edwards. Second, the clash between the majority and dissent foreshadowed subsequent judicial division in important religious freedom cases. The overall tendency is the gradual and complete individualization of religion and the corresponding diminution of religious freedom's institutional dimensions.

Before further exploring this tendency, it bears asking whether the Court's discussion of business corporations has steered the debate over institutional religious freedom off course. In most cases, it has led to confusion. Peter Hogg, for instance, writes that some of the rights included in the Charter, whether guaranteed to "everyone" or to "any person," are "by their very nature not available to a corporation." 171 Using Big M and Edwards as support, Hogg specifies that section 2(a) is inapplicable to corporations, as the latter "cannot hold a religious belief or any other belief." 172 One reason is that religious freedom is "founded in respect for the inherent dignity and the inviolable rights of the human person." ${ }^{173}$ Hogg nonetheless also acknowledges the peculiarity posed by religious

169. Ibid at 679 [emphasis added].

170. Ibid, citing Edwards, supra note 162 at 784, Dickson CJC.

171. The Charter includes several rights and freedoms, which, because of their very nature, may not be invoked by a corporation. For example, Hogg notes that "the right to fundamental justice under s. 7 does not apply to a corporation, because it is limited to deprivations of 'life, liberty and security of the person' which are attributes of individuals." See Hogg, supra note 132, ch 37.1(b), 37-2.

172. Ibid [emphasis added].

173. Big M, supra note 7 at 336 . 
organizations and bodies. He affirms that "[ $\mathrm{t}]$ here may be some corporations that are formed for the exercise of religious beliefs, for example, a church organized as a corporation." ${ }^{174}$ But Hogg does not make clear whether religious freedom would inhere in the corporation itself or rather in the individual congregants constituting the religious community.

This latent ambiguity appears to be another key reason why Chief Justice Dickson declined to determine the issue of religious corporations in Edwards. Although the appellant in that case was not a religious corporation and the Court ultimately rejected a business corporation's ability to invoke section 2(a), Chief Justice Dickson raised the question of a religious corporation's freedom of religion in obiter. For Chief Justice Dickson:

A more difficult question is whether a corporate entity ought to be deemed in certain circumstances to possess the religious values of specified natural persons. If so, should the religion of the directors or shareholders or even employees be adopted as the appropriate test? What if there is a divergence of religious beliefs within the corporation? ${ }^{175}$

Answering these questions about religious corporations one way or another would not entirely solve the issue of whether a collective dimension of religious freedom exists under the Charter because the question of whether a non-incorporated church, religious community, or collective may invoke section 2(a) would still remain open. Despite considerable judicial disagreement in several key religious freedom cases, this question has yet to be conclusively determined by the Court.

The discussion of the possible section 2(a) rights of religious corporations is a distraction from a more important debate, however. When a business corporation has a religious objection to a law, it is because its directors or shareholders, individually or collectively, have reservations about it due to their individual beliefs. Ultimately, the case of the business corporation can be resolved as a special—and perhaps even subordinate-claim of religious individualism in which the different stakeholders' rights are infringed. Nearly all cases of business corporations that have come before the courts fall under this model.

174. Hogg, supra note 132, ch 37.1(b), 37-2, n 3.

175. Edwards, supra note 162 at 785. 


\section{TRINITY WESTERN AND THE IRREDUCIBILITY OF INSTITUTIONAL CONCERNS}

The other side of the discussion over corporate form and religious rights is the relationship between individuals and institutions. This is a problem about derivability of rights: whether the institutional aspects of religion are merely the aggregation of individual rights-claims. A robust religious institutionalism argues that at least some important religious rights are not derivable from individual claims but rather that those individual claims are constituted by the institutional practice or by belief in the religious necessity of a certain institutional form. A robust institutionalism further recognizes that its distinctiveness compared to religion's individual dimensions may give rise to concurrent infringements of the religious freedom belonging respectively to the institution and to its adherents and that these infringements may themselves take different forms. In other words, the same state action may infringe religious freedom in both its individual and institutional dimensions. We have discussed the philosophical and historical accounts in previous sections; here, we offer some examples of the deleterious effect that a denial of the distinct institutional claims of religious freedom has had on the case law.

The Supreme Court of Canada had the opportunity to engage directly with post-Charter religious institutionalism in Trinity Western University $v$ British Columbia College of Teachers. ${ }^{176}$ Trinity Western centered on a private religious educational institution associated with the Evangelical Free Church of Canada. Under an agreement with the British Columbia College of Teachers ("BCCT"), TWU established a five-year teacher training program. Enrolled students spent four years of the program at TWU, while the fifth year was spent at Simon Fraser University. Eventually, TWU applied to assume full responsibility for the program. The BCCT denied the application, citing TWU's "Community Standards" document, which students signed as a condition of attendance at the school and which proscribed "homosexual behavior." 177 The BCCT found that teachers educated in TWU's program would be likely to foster discriminatory practices in the public school system. ${ }^{178}$

While recognizing the role of private religious institutions in the diversity of Canadian society, ${ }^{179}$ the Court's analysis focused on the religious freedom of individual students attending TWU's teaching program who were adversely

176. Trinity Western, supra note 8.

177. Ibid at paras 2-4.

178. Ibid at para 5 .

179. Ibid at paras 33-34. 
affected by the BCCT's decision. This case was not about affirming TWU's religious freedom under section 2(a); rather, the central issue was "to reconcile the religious freedom of individuals wishing to attend TWU with the equality concerns of students in BC's school system." 180 The BCCT's holding prevented TWU students "from expressing freely their religious beliefs" and "associating to put them into practice." 181 The BCCT's failure to consider these effects on religious freedom rendered its decision unreasonable.

To consider the effect of the BCCT's decision on TWU students, however, only captures a fraction of the religious freedom issues involved. Religious students at any institution are free to make private or public pledges of adherence to what they consider biblically mandated standards of sexual morality, but what was at stake here was the licensing of an educational program that prescribed adherence to such a standard as a condition of attendance. On the one hand, this concerns the ability of a private religious institution to prescribe behavioural standards as conditions to admission and continued membership. On the other, it concerns the ability of individual students to attend an institution that prescribes these standards. No aggregation of individual student beliefs can yield the desired institutional outcome. ${ }^{182}$ This is not to say that the outcome in Trinity

180. Ibid at para 28 [emphasis added].

181. Ibid at para 32 [emphasis added].

182. To the Court's credit, Iacobucci J and Bastarache J discussed the fact that the British Columbia Human Rights Code explicitly exempts a religious institution from its provisions "where it prefers adherents of its religious constituency." See Trinity Western, ibid at para 35. Therefore, it would be unreasonable to conclude that the religious beliefs of private institutions are protected by the Human Rights Code but their graduates are not. See Human Rights Code, RSBC 1996, c 210, s 41. A similar exemption is common in human rights statutes across Canada. See e.g. Human Rights Code, RSO 1990, c H19, s 24(1). Ontario's Human Rights Code was discussed in Christian Horizons. See Christian Horizons, supra note 54. The Court addressed an analogous issue in Reference re Same-Sex Marriage, where it categorically stated that "the guarantee of religious freedom in s. 2(a) of the Charter is broad enough to protect religious officials from being compelled by the state to perform civil or religious same-sex marriages that are contrary to their religious beliefs." See Reference re Same-Sex Marriage, 2004 SCC 79 at para 60, [2004] 3 SCR 698. The subsequent legislation "recognized that officials of religious groups are free to refuse to perform marriages that are not in accordance with their religious beliefs." See Civil Marriage Act, SC 2005, c 33, s 3. This, however, leaves some ambiguity about the capacity of a religious official whose beliefs favour the permissibility of same-sex marriage but whose congregation forbids it. Would a religious official be acting ultra vires by performing a same-sex marriage in that case and thus relinquish the dispensation that being a 'religious official' confers? Note that this right is, again, not primarily an individual right (which would protect religious persons in whatever capacity) but rather one derived from one's status as a religious official (which presumes an institutional authority capable of naming the official in question). 
Western would have been different had the Court directly engaged with the evident institutional dimensions raised by the litigation. Instead, Trinity Western stands out as a missed opportunity to fully engage with religious institutionalism. Indeed, even though TWU was ultimately victorious, the Court's exclusive focus on religion's individual dimensions makes its judgment deficient. If an institutional religious freedom claim is itself individualized, or if the institution's claims are not otherwise treated as institutional in nature, the victorious outcome is secondary. The victorious outcome would be arrived at despite the failure to engage with institutionalism on its actual terms or to recognize the particularity of the claims and interests involved. In instrumental terms, the victorious outcome might be paramount, but from the perspective of legal doctrine, such an outcome would be unfavourable. Indeed, as argued by Howard Kislowicz, "[A]n incomplete understanding of [religious] practice necessarily means an incomplete analysis of the impact of a particular policy on religious freedom." ${ }^{183}$

\section{AMSELEM AND THE SUBJECTIVIZATION OF RELIGION}

The invocation of institutional authority sits uneasily with the current high mark in the Supreme Court of Canada's religion jurisprudence, Amselem. ${ }^{184}$ The case arose when a condominium association denied several Orthodox Jewish apartment owners permission to build individual sukkahs-temporary shelters where observant Jews traditionally take their meals during the festival of Sukkot - on their balconies. The association cited the building's by-laws, which prohibited the erection of temporary structures on balconies. The association offered instead to set up a communal sukkah on the grounds of the building, but the owners did not consider this acceptable according to their understanding of the religious requirements of the holiday. At trial, both sides presented expert testimony from religious authorities on the proper, objective interpretation of the religious requirement.

The issue in Amselem did not directly implicate religious institutions. It was not the rights of a congregation, but rather those of individuals, that were at stake. But the Court's articulation of religious freedom extended the individualistic conception introduced in $\mathrm{Big} M$ and made it even more difficult to appreciate the institutional aspects of religion. This articulation also enables courts to avoid disputes concerning religious doctrine entirely. ${ }^{185}$ Religious freedom, wrote Justice Iacobucci, "is integrally linked with an individual's self-definition and

183. Kislowicz, supra note 105 at 189.

184. Supra note 7.

185. Kislowicz, supra note 105 at 167. 
fulfillment." 186 This is because "freedom of religion exists in a matrix of other correspondingly important rights that attach to individuals." 187 Indeed, religious freedom concerns "freely and deeply held personal convictions or beliefs ... the practices of which allow individuals to foster a connection with the divine." 188 It is connected to an individual's spiritual faith," and inheres first and foremost as "a function of personal autonomy and choice." 189 An individual's sincere religious belief may be protected "irrespective of whether a particular practice or belief is required by official religious dogma or is in conformity with the position of religious officials." 190 The only requirement is that the interference be "more than trivial or insubstantial." 191

This conception of religion has been called "subjective" for its exclusive reliance on the sincerity of the individual believer when determining whether a religious interest is at stake and is contrasted with an "objective" criterion that would require, as Justice Bastarache wrote in his dissent, that "[a] nexus between personal beliefs and the religion's precepts ... be established." 192 The complete subjectivization of religion tends to reduce it, as we have noted before, to a special claim of conscience, which renders the difference between religion and conscience irrelevant and pushes institutions out of the religious landscape. Yet it is not the individual case of religious freedom that tests the distinction between subjective and objective, but rather the institutional case. In the individual case, the distinction may be overblown, as Daniel Weinstock suggests in the article discussed in Part II, above. ${ }^{193}$ While an objective criterion may require that a claimant make reference to an "authoritative script" in establishing a religious conviction, this script need not be filtered through a religious official and its interpretation may be idiosyncratic. ${ }^{194}$ To be sure, a claimant will not

186. Amselem, supra note 7 at para 42.

187. Ibid at para 1 .

188. Ibid at para 39.

189. Ibid at paras 39, 42.

190. Ibid at para 46. This definition was adopted in Multani. See Multani v Commission scolaire Marguerite-Bourgeoys, 2006 SCC 6 at para 33, [2006] 1 SCR 256.

191. Ibid at paras 59-60. Interestingly, this second step in the Amselem test marks the return of objectivity as a controlling standard. The correct question when considering an infringement of section 2(a) is "whether a religious practice or belief exists that has been infringed" and not whether the claimant, subjectively and sincerely "believes that a religious practice or belief has been infringed." See SL v Commission scolaire des Chênes, 2012 SCC 7 at para 24, [2012] 1 SCR $235[S L]$.

192. Amselem, supra note 7 at para 135.

193. "Beyond Objective," supra note 51.

194. Ibid at 171-72. 
be precluded from demonstrating that a religious belief or practice is tied to an objective, communal, or institutional religious precept, and such a precept may be evidence of sincerity. But he or she will not be required to do so; objective external commands are thus transformed into subjective articles of conscience. ${ }^{195}$ While such subjective reliance might be sufficient for a religious tradition that is suspicious of or indifferent to religious institutions, ${ }^{196}$ it is ill-equipped to capture the claims made in the name of collective or corporate religious entities that might not fit the moral psychology of "an individual's self-definition and fulfillment.".197

The conception of religion in Amselem has been called "decentralizing"198 for its effect of shifting religious authority away from established hierarchies and towards the individual. It is not that Amselem is wrong in its protection of idiosyncratic religious believers; that is preferable to the alternative, which is a plurality of imposed orthodoxies. The problem is that Amselem's conception of religion so distorts religious practice that it inhibits the articulation of any institutional dimension of religion. Amselem is the crucible of the Court's insistence on divorcing religious freedom from its historical trajectory, on re-emphasizing religious freedom as a mere variant of freedom of conscience, and on refusing to extend constitutional protection beyond the concept's individual dimensions. The reduction of religion to mere subjective belief strips the concept of its necessary institutional context, which, as intimated above, fulfills a fundamental structural role. Furthermore, Amselem has also severely impaired the intellectual instruments available to jurists in religious freedom litigation.

195. Benjamin L Berger, "Section 1, Constitutional Reasoning and Cultural Difference: Assessing the Impacts of Alberta v. Hutterian Brethren of Wilson Colony" (2010) 51 Sup Ct L Rev (2d) 25 at 31 [Berger, "Section 1"].

196. Richard Moon suggests this as a possible interpretation of Iacobucci J's (Protestant) opinion and Bastarache J's (Roman Catholic) dissent:

The justification and scope of freedom of religion was initially shaped by a Protestant conception of religious adherence, which saw religious belief as a personal and private commitment based on individual reason and judgment. Justice Bastarache may be drawing on a different conception of religion, and religious commitment; one that emphasizes the social and institutional character of religion, and regards religious belief not simply as a personal matter, but as tied to an established system and an institutional structure.

See Richard Moon, "Religious Commitment and Identity: Syndicat Northcrest v. Amselem" (2005) 29 Sup Ct L Rev (2d) 201 at 209.

197. But see Muñiz-Fraticelli, Pluralism, supra note 20 at 186-222 (arguing in favour of the development of personality in associations like churches).

198. Berger, "Law's Religion," supra note 107 at 295-96, 303, 307-308. 


\section{E. HUTTERIAN AND THE INTEREST IN COMMUNITY}

The irreducibility of institutional religious freedom to individual religious freedom is not only in play in cases where it is the institution itself that raises a section 2(a) claim. Sometimes, the individual claim itself presupposes an institutional or communal context absent which the individual right is not properly apprehended, as the individual claim is partly constituted by the institutional context. Indeed, as suggested in our discussion of Trinity Western, individual claims and infringements of religious freedom may be concurrent with claims and infringements of an institutional nature, making judgments that fail to address the latter ultimately deficient. This is the case, most notably, in Alberta v Hutterian Brethren of Wilson Colony, ${ }^{199}$ which "confirms for us that, as far as Canadian constitutionalism is concerned, freedom of religion is ultimately a matter of autonomy and choice." 200

Hutterian involved a constitutional challenge of Alberta's drivers' licensing regulations by a Colony of Hutterites formally constituted through the legal form of the corporation. ${ }^{201}$ Regulations that previously exempted religious adherents from having their photographs taken were amended to make photographs mandatory on all drivers' licences issued in the province. The Colony challenged the regulation under section 2(a), claiming a violation of their community's religious freedom: The inability of members to drive legally might not have a great impact on each of them individually, but it would impose great cost on the maintenance of their communal lifestyle by preventing them from performing tasks necessary to sustain it.

In a four-to-three decision, the Court held that the regulation, while infringing individual Hutterites' religious freedom, was justified under section 1. ${ }^{202}$

199. 2009 SCC 37, [2009] 2 SCR 567 [Hutterian].

200. Berger, "Section 1," supra note 195 at 37.

201. See Kislowicz, supra note 105 at 177-78. Kislowicz cites the affidavit of Samuel Wirz, a member of the Wilson Colony, who confirms that the Colony was a religious communal organization constituted as a corporation.

202. Hutterian, supra note 199 at paras 4, 47, 104. Justification is established by demonstrating: first, that the limitation addresses a pressing and significant concern of sufficient importance to warrant overriding a Charter right or freedom and second, that there is proportionality between the infringement and the means employed to achieve the legislative objective. See e.g. PSAC v Canada, [1987] 1 SCR 424 at 439, 38 DLR (4th) 249. Proportionality is established by showing: first, that there is a rational connection between the legislative objective and the infringement; second, that the measure limits the right or freedom no more than necessary to achieve the objective; and third, that the salutary effects of impairing the right or freedom outweigh the deleterious consequences. See e.g. Hutterian, supra note 199 at paras 47, 53-54, 72-74. 
Chief Justice McLachlin held that the deleterious effects of the photograph requirement on adherents' religious freedom did not outweigh its salutary consequences: "A limit on the right that exacts a cost but nevertheless leaves the adherent with a meaningful choice about the religious practice ... will be less serious than a limit that effectively deprives the adherent of such a choice." ${ }^{203}$ By contrast, Justices Abella and LeBel separately held that the infringement could not be justified. Whereas the majority conceived of the Hutterites' claim in individualistic terms, Justices LeBel and Abella both emphasized its collective dimensions. The importance of this divergence cannot be understated. In fact, according to Justice LeBel, this "may perhaps explain [the majority's] cursory treatment of the [Brethren's] rights ... in the course of the s[ection] 1 analysis." 204 Justice Abella also highlighted the claim's collective nature. Reminding the Court that "freedom of religion has both individual and collective aspects," she noted that both aspects were engaged. ${ }^{205}$ Justice Abella found that the amendment would completely extinguish the Colony's autonomous way of life and could therefore not be justified under section $1 .{ }^{206}$ In Justice Abella's words, "To suggest ... that the deleterious effects are minor because the Colony members could simply arrange for third-party transportation, fails to appreciate the significance of their self-sufficiency to the autonomous integrity of their religious community." 207

This point was echoed by Justice LeBel, for whom freedom of religion is both "complex and highly textured." ${ }^{208}$ Courts must recognize that section 2 (a) "incorporates a right to establish and maintain a community of faith," as well as other collective dimensions. ${ }^{209}$ Religion is a communal experience for many adherents, which entails a nuanced constitutional analysis. In the words of Justice LeBel:

Religion is about religious beliefs, but also about religious relationships. [This case] signals the importance of this aspect. It raises issues about belief, but also about the maintenance of communities of faith ... that share ... a common faith and a way of life that is viewed by its members as a way of living that faith and of passing it on to future generations. ${ }^{210}$

203. Ibid at para 95.

204. Ibid at para 182.

205. Ibid at paras 130-31.

206. Ibid at paras 163-66.

207. Ibid at para 167.

208. Ibid at para 181.

209. Ibid.

210. Ibid at para 182 [emphasis added]. 
Interestingly, Chief Justice McLachlin did not dispute that religion includes individual and collective aspects. However, she emphasized, most contentiously, the importance of clarity about "the relevance of those aspects at different stages of the [section 1] analysis." ${ }^{111}$ Whereas the dissent would have considered community impact at every stage, the Chief Justice held that it was only relevant at the balancing stage of the proportionality analysis. As such, even where community impact is established, it does not "transform the essential claim-that of the individual claimants for photo-free licenses-into an assertion of a group right." ${ }^{212}$ This characterization should not surprise those familiar with the Court's jurisprudence on section 2(a), for while the majority acknowledges religion's dual strains, it repeatedly re-emphasizes religion's individualistic dimension. As a result, "one is left with a sense of a failure to grapple what it means to the traditional life of this religious community to lose the self-sufficiency that it enjoyed by having members that are able to drive." ${ }^{213}$

It seems probable that the decision would had been different if the Hutterites' concerns for "the autonomous integrity of their religious community" had been taken seriously as intrinsic to and constitutive of their religious practice, not as an incidental expression of their faith. In the first place, such a consideration would have reflected the Hutterites' own understanding of their religious obligation as situated in their communal institutions. Second, by multiplying the objections of individual Hutterites to the photography requirement by the injury posed to their communal mode of life, it would have increased the total weight of the section 2(a) infringement, shifting the balance away from section 1 justification. The later adoption of Justice Abella's dissenting position in Hutterian by the majority in Loyola, which gave victory to a religious institution over a provincial regulation, is evidence of this shift.

Howard Kislowicz has observed that the majority's judgment in Hutterian is emblematic of a failure to give proper respect to two central values: respect and self-awareness. On one side, the majority's avoidance of the communal dimensions of the Hutterites' religious freedom demonstrates a failure to respect the litigants, ${ }^{214}$ insofar as it denies the Colony's independent agency as a religious community organized as an institution. On the other, the majority's failure to engage with those same dimensions typifies the Court's lack of self-awareness

211. Ibid at para 31 .

212. Janet Epp Buckingham, "Drivers Needed: Tough Choices from Alberta v. Wilson Colony of Hutterian Brethan" (2010) 18:3 Const Forum Const 109 at 112.

213. Berger, "Section 1," supra note 195 at 40 [emphasis in original].

214. Kislowicz, supra note 105 at 188. 
concerning its normative commitment to individualism. ${ }^{215}$ It may be, however, that the majority was in fact fully aware of this normative commitment and refused to budge when confronted with the claims asserted by the Wilson Colony. ${ }^{216}$

Richard Moon observes that the decision in Hutterian is "not out of line" with cases such as Edwards and Trinity Western, in which the Court accepted accommodation "only because, in its view, the exception would not compromise the law's purpose in any meaningful way." 217 In these cases, the Court was only prepared to accept a minimal impairment of governmental purpose. The result of the Court's jurisprudence has been an erosion of minority religious rights, no doubt because the common life of these groups often takes forms at odds with the majority's legal order. ${ }^{218}$ From the perspective religious minorities, this erosion has in turn given rise to resistance to the perceived hegemony of state secularism and to a subtle shift from freedom of religion to freedom from the secular. ${ }^{219}$ Religious freedom generally, and institutionalism specifically, is here being used as a shield to protect religious groups from intrusion by a secular government rather than as a sword to forcibly impose sectarian interests on the broader community through constitutional litigation.

But the measure of impairment depends, in part, on what interests are being impaired. If only individual interests, considered separately, are at stake, the impairment may appear small in each case and to each person. If the collective effects of state action are taken into account, however, it becomes clearer that some governmental action severely interferes with the ability of religious communities to sustain a common life. Now, collective interests are not necessarily institutional. It is one thing for members of a religious community to ask courts to consider the impact of regulation on their ability to maintain a common life and another for a formally constituted religious institution to assert its own interests in autonomy and self-governance. But the institutional

215. Ibid.

216. Kislowicz observes that the Court's refusal to budge may be attributed to the fact that "the deep collectivism of the Hutterite worldview ... reveal[ed] a view of religion at odds with the Court's focus on the individual aspects of religious practice." See Kislowicz, ibid at 157.

217. "Accommodation Without Compromise: Comment on Alberta v. Hutterian Brethren of Wilson Colony" (2010) 51 Sup Ct L Rev (2d) 96 at 128. See also Marshall Haughey, "The Camera and the Colony: A Comment on Alberta v. Hutterian Brethren of Wilson Colony" (2011) 74:1 Sask L Rev 59; Sara Weinrib, "An Exemption for Sincere Believers: The Challenge of Alberta v. Hutterian Brethren of Wilson Colony" (2011) 56:3 McGill LJ 719.

218. Margaret H Ogilvie, "The Failure of Proportionality Tests to Protect Christian Minorities in Western Democracies: Alberta v Hutterian Brethren of Wilson Colony" (2010) 12:2 Ecclesiastical LJ 208 at 213.

219. Berger, "Religious Diversity," supra note 108 at 113-14. 
1098 (2015) 52 OSGOODE HALL LAW JOURNAL

is best seen in relation to the collective, as religious institutions are a way for religious communities to sustain and focus common endeavours. For some, religious institutions may be necessary for religious doctrine to be defined and religious practice to be carried out. As indicated above, the Wilson Colony, a religious community, had chosen to organize itself under the legal form of the corporation, the secular vehicle through which a religious community or group expresses itself to and is cognizable by secular state institutions, including the law. In any event, whether the collectivity is formally institutionalized or not, the interests involved are constituted by the collective endeavour and are distinct from whatever interests the individual conscience may invoke.

Despite these problems, Hutterian had some positive implications. The decision signalled the need for further judicial consideration of the ambiguities raised by the majority and dissent. As Janet Epp Buckingham suggested, "Given that [Hutterian] is a split decision by a less than full panel of the Supreme Court of Canada, it is not likely the final word on the place of the communal aspects of religion" in Canadian constitutional culture. ${ }^{220}$ Rather, it is the opening salvo of further deliberation. This proved true in Loyola, in which the central argument of Hutterian was effectively (and surprisingly) reversed.

\section{F. LOYOLA AND THE RECOVERY OF RELIGIOUS INSTITUTIONALISM}

We come, at last, to Loyola, which promised to be the case that would definitively answer the question of whether religious institutions were directly protected by section 2(a) freedom of religion. ${ }^{221}$ To some extent, the Court acknowledged the importance of religious institutions, but a narrow majority again avoided the direct question of the rights of religious organizations. Still, Loyola is an important case in many respects. In addition to its engagement with the collective or institutional aspects of religious freedom, it also elaborates on the proper standard of review of administrative decisions and presents a broad framework for evaluating educational policies that bear on the teaching of religion and ethics in a secular democracy. We will focus here on the issues that bear directly on religious institutions, although these include the permissibility and boundaries of sectarian religious education. We will largely put aside, however, the important but distinct questions of administrative law that are raised in the case. But before delving directly into the Loyola decision, some context about the history of religious education in Quebec is appropriate.

220. Supra note 212 at 116.

221. Supra note 9. 


\section{EDUCATION AND RELIGION IN QUEBEC}

The controversy over the Charter rights of religious institutions in Loyola is distinct from, but related to, the broader controversy over religious education in Quebec. ${ }^{222}$ Our concern is not primarily with the merits of civic or religious instruction. ${ }^{223}$ Yet educational policy is intimately linked to the institutional aspect of religious liberty. The education of children is the way in which a community reproduces itself, whether that community is the state or the church, and the struggle for control of educational institutions reflects a larger struggle over the nature and boundaries of community. ${ }^{224}$ In turn, this struggle provides fertile ground for analyzing the limits of permissible state interference with the autonomy of religious institutions.

The first educational institutions in what is now Quebec were founded by the Jesuit order in the seventeenth century, although "education was a marginal activity in the colony" until the nineteenth century. ${ }^{225}$ Attempts at reform after the British conquest provoked a reaction from Roman Catholic authorities who, perhaps rightly, feared assimilation. ${ }^{226}$ From this moment, the tone of religious education in Quebec was set: It would continue, through to Loyola, to be a battleground over difference, dissent, and assimilation of religious and linguistic

222. Shauna Van Praagh, "From Secondary School to the Supreme Court of Canada and Back: Dancing the Tango of 'Ethics and Religious Culture,"” online: (2012) Fides et Libertas 102 <www.irla.org/assets/public/files/fides/Fides_2012.pdf>. Van Praagh notes, "[T]he Loyola litigation illustrates the difficulty in disentangling the strands of meaning of Ethics and Religious Culture [in Quebec] .... The combination of [SL] and Loyola High School ... represent $[s]$ an invitation to consider who the people are, where they are coming from, and how education, religion, and identity continue to evolve in Quebec in the 21st century" (ibid at 114, 116). We further discuss $S L$ in this section. See infra notes 235-236.

223. For some recent commentary that does concern itself with the intersection of religion, education, and civic participation in the context of the Ethics and Religious Culture curriculum addressed in Loyola, see Berger, "Religious Diversity," supra note 108; Van Praagh, supra note 222. See also Jean-Marc Larouche, "La formation éthique et la citoyenneté démocratique" in Fernand Ouellet, ed, Quelle formation pour l'enseignement de l'éthique à l'école? (Saint-Nicolas, Que: Presses de l'Université Laval, 2006) 173; Daniel Weinstock, "Un cours d'éthique et de culture religieuse: prochain épisode d'un malentendu?" in Ouellet, supra note 223, 187; Pierre Lucier, "Éthique et culture religieuse à l'école québécoise: les défis de la nouveauté" in Ouellet, supra note 223, 197.

224. Berger, "Religious Diversity," supra note 108 at 106, 109, 111. See also Van Praagh, supra note 222 at 106.

225. Roger Magnuson, A Brief History of Quebec Education from New France to Parti Québécois (Montreal: Harvest House, 1980) at 9.

226. Ibid at 24. See also Jean-Pierre Charland, Histoire de l'éducation au Québec: De l'ombre du clocher à l'économie du savoir (Saint-Laurent, Que: ERPI, 2005) at 63. 
minorities_-Roman Catholics and Francophones in English Canada, Protestants and Anglophones in Lower Canada, and now Anglophone Catholics (Loyola's constituency) in an increasingly secular Quebec.

After Confederation, Quebec's educational system continued to be dominated by the Roman Catholic Church, while provision for separate Protestant schools, and reciprocal rights for Catholics in Ontario, were enshrined in the Constitution Act of 1867. The Church resisted state intervention in education, fearful that it would precipitate anticlerical sentiments like those of the French Third Republic and the German Kulturkampf. ${ }^{227}$ The result was complete suppression of public education until the Liberal victory of Jean Lesage in 1960 inaugurated the Quiet Revolution. ${ }^{228}$ A felt need for reorganization and reinforcement of secular educational institutions led to the convening of a royal commission-dubbed the Commission Parent for its president, Monseigneur Alphonse-Marie Parent-to propose thoroughgoing reforms to the educational system. ${ }^{229}$ Only one member of the commission was openly in favor of de-confessionalization. The rest of the members proposed a compromise (only implemented in attenuated form) but guaranteed the continuation of publicly subsidized private schools, including religious schools under ecclesiastical control. ${ }^{230}$ The secular system was not set up until after another commission, the Estates General on Education, recommended the transformation of confessional school boards into linguistic ones (which required an amendment, in 1997, to section 93 of the Constitution Act, 1867) and replacement of sectarian moral education with a cultural and civic counterpart (which would eventually become the Ethics and Religious Culture ("ERC") curriculum). ${ }^{231}$ While de-confessionalization of public schools was formalized in 2000 , and repeals of provisions maintaining student choice in religious and moral

227. Magnuson, supra note 225 at 43.

228. Indeed, the impetus for de-confessionalization of Quebec schools began when the Jesuits made a request to convert the Collège Sainte-Marie-the original Jesuit institution from which Loyola High School was created-into a religious university. See e.g. Gabriel Gosselin \& Claude Lessard, eds, Les deux principales réformes de l'éducation du Québec moderne: Témoignages de ceux et celles qui les on initiées (Quebec: Presses de l'Université Laval, 2007). For primary documents on the debate surrounding the Parent commission, see Claude Corbo \& Jean-Pierre Couture, eds, Repenser l'école: Une anthologie des débats sur l'éducation au Québec de 1945 au rapport Parent (Montreal: Presses Universitaires de Montréal, 2000).

229. Gosselin \& Lessard, supra note 228 at 13. This need for reorganization was the first step in a "fifty-year process of disentanglement of religion and education in Quebec." See Berger, "Religious Diversity," supra note 108 at 111.

230. Gosselin \& Lessard, supra note 228 at 60.

231. Commission for the Estates General on Education, Renewing our Education System: Ten Priority Actions (Quebec: Ministry of Education, 1996) at 82. 
instruction occurred in 2005, the private school system was largely untouched. ${ }^{232}$ The most significant change was the universal implementation of the ERC program in 2008, designed "to prepare children for life in a pluralistic society, to educate them in the range of religious traditions that they might encounter, and to teach them about the religious heritage of Quebec." 233 The program fostered the development of competency in the cultural aspects of world religions, ethics, and dialogue. Key objectives of the program included the recognition of others and the pursuit of the common good. Instruction in religion was to be wholly cultural, with specific exclusion of discussion of doctrine.

In the ERC program's inaugural year, the parents of several children enrolled in a Quebec public school requested that their children be exempted from the program on the grounds that its neutral and pluralistic approach "would inculcate a kind of relativism" 234 that interfered with their parental right to raise their children in accordance with Catholic religious beliefs. The Supreme Court of Canada eventually reviewed the parents' claims in SLv Commission scolaire des Chênes. The Court accepted the parents' sincere belief in the deleterious effect that the course would have on their children but found little evidence that the course would in fact have that effect. The Court recognized " $t]$ he right of parents to bring up their children in their faith [as] part of the freedom of religion guaranteed by the Canadian Charter" 235 but nonetheless concluded that although "exposure can be a source of friction, it does not in itself constitute an infringement" of religious freedom" under the Canadian Charter or Quebec Charter. 236

A central premise of the decision in $S L$ was that the state should remain neutral between different religious traditions and, in particular, express such a neutral position in public instruction. This is a problematic assumption at a philosophical level ${ }^{237}$ but is significantly less problematic when the state itself

232. Bill 118, An Act to amend various legislative provisions respecting education as regards confessional matters, 1st Sess, 36th Leg, Quebec, 2000, ss 53-55; Bill 95, An Act to amend various legislative provisions of a confessional nature in the education field, $1 \mathrm{st}$ Sess, 37th Leg, 2005 (assented to 17 June 2005). The government of Quebec also amended section 41 of the Quebec Charter as well as section 5 of the Education Act in order to eliminate the requirement that confessional religious education be provided in public school, but, again, private schools were largely untouched. See Charter of Human Rights and Freedoms, CQLR c C-12, st 41

[Quebec Charter]; Education Act, RSQ c I-13.3, s 5. The amendment of section 41 is widely regarded as necessary to prevent challenges from religious minorities affected by the changes. 233. Berger, "Religious Diversity," supra note 108 at 112.

234. Ibid.

235. SL, supra note 191 at para 50.

236. Ibid at para 40.

237. Berger, "Religious Diversity," supra note 108. 
is the educator, especially when the non-neutral alternative is considered. ${ }^{238}$ When the state is the educator, it acts as arbiter of opinion and as a speaker in its own right. As such, there ought to be constraints on its expression of favour for one or another religion. However, when the educator is a religious school, the constraints are different since neutrality is necessarily absent. Moreover, religious institutions have a special interest when it comes to religious and moral education because conveying an educational message on these subjects is not limited to communication of facts but includes normative expression and possible endorsement of controversial positions. Religious schools, in effect, are speaking for themselves when they dictate how their teachers address their students, and they have an interest in their message being sincere and consonant with their mission and values. This was the issue in Loyola.

\section{THE ROAD TO LOYOLA}

The Loyola case was brought by Loyola High School, a private Roman Catholic school administered by the Jesuit order. ${ }^{239}$ As part of the school's curriculum, students received instruction on world religions and ethical systems through a program of the school's own design, which was admittedly grounded on a Jesuit and Roman Catholic framework. In March 2008, the school petitioned Quebec's Minister of Education, Recreation, and Sports for an exemption from the mandatory ERC course in order to continue to teach its pre-existing religion and ethics program. Such exemptions were contemplated by section 22 of the Regulation respecting the application of the Act respecting private education. ${ }^{240}$ Loyola argued that its own program was substantively equivalent to the ERC course in the values it fostered and the material it covered. Loyola nonetheless maintained

238. A more radical position - that "children ought not to learn about other religions or at least ought not to learn about them in a way that did not make clear that they were erroneous" is also out of place in public education. See Richard Moon, "Freedom of Religion Under the Charter of Rights: The Limits of State Neutrality" (2012) 45:2 UBC L Rev 497 at $547-48$, n 10.

239. The school is organized as a corporation without share capital in Quebec. See Companies Act, CQLR c C-38, Part III. In addition to the school, John Zucchi, father of a student enrolled in Loyola, appeared as a plaintiff in his own name and that of his son. This was done presumably as a safeguard in the event that Loyola's own religious freedom claims were rejected, but at no point in the proceedings did the case turn on his arguments as distinct from those of the schools or the "Loyola community" in general.

240. CQLR c E-9.1, r 1, s 22 [Private Education Regulation]. Section 22 reads: "Every institution shall be exempt from the application of the first paragraph of section 32 of the Act respecting private education (chapter E-9.1) provided the institution dispenses programs of studies which the Minister of Education, Recreation and Sports judges equivalent." 
that the ERC course's proposed neutrality (which, Loyola argued, was conducive to moral relativism) was incompatible with the school's Catholic mission. ${ }^{241}$ The Minister denied the school's request, arguing that no course taught from a confessional or sectarian perspective could be deemed equivalent to the ERC. Furthermore, the Minister contended that Loyola's course addressed religious faith directly (not merely its cultural aspects) and examined other religions and ethical dilemmas with reference to Roman Catholicism (instead of taking them on their own terms without reference to another tradition).

Loyola brought the suit on its own behalf as a private Catholic institution. The substance of its argument was that the Minister's refusal to exempt it from teaching ERC amounted to state coercion over religious instruction, forcing Loyola to teach religion and ethics contrary to Catholic precepts. Loyola argued that this constituted an infringement of its rights to religious expression, belief, and practice under the Canadian Charter and Quebec Charter, as it impeded the school's religious mission in three important ways: first, the refusal to grant an exemption prevented Loyola from teaching ethics and religion according to its religious approach; second, it forced Loyola to teach religion and ethics from a secular perspective; and third, it deprived the school of the meaningful choice to continue adhering to its religion. The refusal placed Loyola in an untenable position: either it could teach ERC according to secular Ministerial direction and violate its own religious precepts or it could teach ethics and religious culture in a manner faithful to its religious precepts and violate the law. ${ }^{242}$ The Minister argued that Loyola, as a corporate non-natural person, was precluded from invoking the constitutional guarantee of freedom of religion under the Canadian Charter and Quebec Charters. Alternatively, the Minister maintained that even if Loyola was directly protected by religious freedom, the ERC program and the denial of an exemption constituted reasonable limitations on those rights. ${ }^{243}$

The school won at the trial level. In a lengthy judgment centrally concerned with then unsettled aspects of administrative law, the judge determined that, given the character of the school, the practice of religious instruction, and the use of the word "person" in the Canadian Charter and Quebec Charter, nothing in the law precluded a corporate person from invoking freedom of religion. The Court of Appeal overturned the ruling, however. This was due in part to the

241. The exchange of letters between the Minister and the school is included in the trial court opinion. See Loyola High School c Courchesne, 2010 QCCS 2631 at paras 31-40, [2010] RJQ 1417 [Loyola, QCCS].

242. Ibid at paras $265,268-69$.

243. Loyola, supra note 9 at paras 30-31. 
Supreme Court of Canada's intervening decision in Doré v Barreau du Québec on the proper standard of review of administrative decisions involving Charter provisions. ${ }^{244}$ But the appellate opinion also engaged, somewhat tangentially, the question of Loyola's own freedom of religion. The Court of Appeal dismissed outright the idea that there was any special consequence to the religious nature of the school ${ }^{245}$ and refused (as the Supreme Court of Canada had always done) to answer the question of institutional religious freedom directly. Taking a page from $H y$ and Zel's, the Court of Appeal merely assumed, for the purpose of its analysis, that Loyola, as a corporation, could enjoy constitutional protection of freedom of religion and that it had demonstrated a sincere belief regarding its religious duty to teach the ERC program from a Catholic perspective. ${ }^{246}$ Yet in the end, the appellate court concluded that the Minister was entitled to deference in her refusal of Loyola's request for an exemption specifically because the proposed substitute was religious in nature. ${ }^{247}$ The Court of Appeal also characterized the infringement of Loyola's religious rights as negligible. ${ }^{248}$ Citing Hutterian, it held that the imposition of a single ERC class does not truly threaten religious belief or behaviour, as Loyola retained control over the majority of its educational and

244. 2012 SCC 12 at paras 55-56, [2012] 1 SCR 395 [Doré]. Rendered after the trial court's decision, Doré established that challenges to administrative decisions on Charter grounds are to be analyzed under administrative law principles (ibid at paras 55-58). Therefore, courts may no longer subject such decisions to the s 1 Oakes analysis under the Charter or to the s 9.1 analysis under the Quebec Charter. However, in an exercise of "cross-fertilization" of Charter and administrative principles, Doré also provides that administrative decision makers, including Ministers, are bound to consider Charter values in rendering their decisions. As an "enriched conception of administrative law," the Charter analysis of administrative decisions will centre on proportionality-that is, on ensuring that the Ministerial decision (or action) interferes with the affected Charter guarantee no more than is necessary in order to achieve the statutory objectives. A decision that fails to satisfy this test will be deemed unreasonable under the reasonableness standard of judicial review. Indeed, the manner that deference to legislative choice is applied in the Oakes test is expressed with exactly the same language as we find under reasonableness review in administrative law: In both cases, the government's action must fall within a range of reasonable constitutional alternatives. See E Fox-Decent, "The Charter and Administrative Law: Cross-Fertilization in Public Law" in Colleen M Flood \& Lorne Sossin, eds, Administrative Law in Context, 1st ed (Toronto: Emond Montgomery, 2008) 169; E Fox-Decent \& A Pless, "The Charter and Administrative Law: Cross-Fertilization or Inconstancy" in Colleen M Flood \& Lorne Sossin, eds, Administrative Law in Context, 2nd ed (Toronto: Emond Montgomery, 2013) 407 at 422-24.

245. Québec (Procureur général) c Loyola High School, 2012 QCCA 2139, [2012] RJQ 2112.

246. Ibid at paras 167-68.

247. Ibid at paras $13,120,124,126$.

248. Ibid at para 168. 
religious curriculum. ${ }^{249}$ In the Court of Appeal's view, nothing in the Minister's decision placed an obstacle to Catholic doctrine and faith. ${ }^{250}$ Thus, in exercising the discretion conferred under the Private Education Regulation, ${ }^{251}$ the Minister correctly balanced Loyola's assumed Charter rights to religious freedom with the statutory objective of secularizing the Quebec school system.

The Supreme Court of Canada asked the parties to address directly both the question of whether Loyola enjoyed religious freedom under section 2(a) and whether the Minister's decision bore scrutiny under the appropriate standard of review. The two questions were related since Loyola argued that whether the standard of review was correctness (as the trial court held) or reasonableness (as the Court of Appeal found), the Minister's decision would not bear scrutiny precisely because she had not properly considered the right at issue, namely the institutional religious freedom of the school. Eleven intervenors filed briefs with the court, all in support of Loyola's request for an exemption and all but one in support of the position that religious freedom should extend to at least some corporate bodies. ${ }^{252}$

Ironically, in the final decision, a majority of the Court again expressly declined to answer the fundamental question of religious institutionalism but in the process clarified the positions at stake and pointed towards a horizon on which they might be resolved. The judges unanimously decided in favor of Loyola but were divided over important details about the nature and implications of the rights in question and the extent of religious protection to teach a confessional curriculum, in addition to the immediate remedy to be provided in the case. Justice Abella, writing for the majority, found that section 2(a) of the Charter protected the "religious freedom of the members of the Loyola community who seek to offer and wish to receive a Catholic education" 253 but did not find it necessary to decide if corporations themselves were constitutionally protected. ${ }^{254}$ Applying the Doré framework of proportionality, she concluded that the Minister's refusal to deny Loyola the right to teach Roman Catholicism from a confessional perspective was

249. Ibid at paras 173-74.

250. Ibid at para 182 .

251. Private Education Regulation, supra note 240.

252. The exception was the Faith, Fealty \& Creed Society, a charity apparently formed for the express purpose of intervening in the case. Its arguments are interesting, as they express a strong Congregationalist stance at odds with the more hierarchical position upheld by Loyola and the Roman Catholic interveners. See Loyola, supra note 9 (Factum of the Intervener at paras 7, 10-17, 25-33).

253. Loyola, supra note 9 para 32.

254. Ibid at para 33. 
disproportionate to the valid state objectives in the ERC curriculum. However, the importance of these objectives - which had been deemed constitutional in $S L^{255}$-also limited the scope of Loyola's exemption to the teaching of Roman Catholic religion and ethics. ${ }^{256}$ Other religious traditions and religious ethics would have to be taught from the neutral perspective advocated by the ERC program, although "[a] school like Loyola must be allowed some flexibility as it navigates these difficult moments [of teaching other ethical frameworks]."257

The concurrence of Chief Justice McLachlin and Justice Moldaver was significantly more accommodating of Loyola's claim. From the start, Chief Justice McLachlin and Justice Moldaver concluded that "Loyola as a religious organization is entitled to the constitutional protection of freedom of religion." 258 Such protection is required as a condition of protecting individual freedom of religion ${ }^{259}$ but is not derived from or predicated on the religious freedom of teachers, parents, or students (and presumably other individual members) of the institution. ${ }^{260}$ It is "the religious freedom of Loyola itself." ${ }^{261}$ As to the Minister's substantive reasons for refusing Loyola an exemption from the ERC program, the concurrence denied that the objectives and competencies of the ERC program

255. SL, supra note 190 at paras 26-27 (holding that the ERC does not infringe on the Charter rights of Roman Catholic parents of children attending public school).

256. It is important to note that at the trial level, Loyola had sought an exemption from the entire ERC curriculum, but by the time the case reached the Supreme Court of Canada, it had modified its position, asking instead for a more limited exemption to teach Roman Catholic religion and ethics from a confessional perspective. Thus, the Court's ruling agreed with the school's modified demand. See Loyola, supra note 9 at para 31.

257. An important confusion in the majority decision, but not one pertinent to our discussion, is the conflation of the religion and ethics components of ERC. The two are distinct in the course, but the majority opinion only refers to "religious ethics." Daniel Weinstock, one of the drafters of the ethics component of the course, expressed frustration with this aspect of the decision, observing that while the Court opinion

clearly does prohibit Loyola from teaching ethics from a narrowly confessional Catholic perspective, it implies that ethical discussion normally occurs from within religious perspectives, and that the kind of fairness and neutrality implied in the [ERC] involves being fair between the ethical frameworks contained in different religious traditions, rather than separating ethics and religion altogether. This is precisely the denial of the autonomy of ethics with respect to religion that I had seen as a risk when the course was first introduced.

See Daniel Weinstock, "What Did Loyola Really Decide?” (21 March 2015), In Due Course (blog), online: <www.induecourse.ca/what-did-loyola-really-decide>.

258. Loyola, supra note 9 at para 88.

259. Ibid at paras 91-94.

260. Ibid at para 130.

261. Ibid at para 131. 
could only be taught from a cultural and non-denominational perspective. Instead, it should be sufficient for Loyola's teachers to "describe and explain the ethical beliefs and doctrines of other religions in an objective and respectful way" while maintaining "a respectful tone of debate."262

\section{THE ROAD FROM LOYOLA}

It is too early to draw any conclusions about the possible effects of the Loyola decision, but some preliminary analysis is warranted. ${ }^{263}$ Three vectors of disagreement seem especially relevant. The first concerns the identity of the rights-holder: Justice Abella's majority opinion is concerned with "the religious freedom of members of the Loyola community," ${ }^{264}$ while the concurrent opinion authored by the Chief Justice and Justice Moldaver argues directly for the religious freedom of the institution. Now, some authors have argued that communities can be rights-holders. ${ }^{265}$ These rights are grounded in the presence of collective interests, of factors contributing to the common good of its members. ${ }^{266}$ This position seems close to Justice Abella's majority opinion in Loyola and consistent with her previous dissent in Hutterian, where she argued precisely that the collective interest of Hutterites in preserving their way of life required a different balance of interests than the consideration of individual members. According to her majority reasons in Loyola:

Religious freedom under the Charter must ... account for the socially embedded nature of religious belief, and the deep linkages between this belief and its manifestation through communal institutions and traditions ....... The Minister's decision therefore demonstrably interferes with the manner in which the members

262. Ibid at para 162 .

263. Loyola has been briefly referenced once already by the Supreme Court of Canada. See Mouvement lä̈que québécois v Saguenay (City), 2015 SCC 16, [2015] 2 SCR 3 (referencing Loyola briefly on the general principle of administrative review). It was also mentioned without comment by the Alberta Human Rights Tribunal. See Amir and Nazar v Webber Academy Foundation, 2015 AHRC 8 at para 123. For a more interesting discussion, see Fondation internationale Azzahra inc c Cour du Québec, 2015 QCCS 1307 at paras 63-64, 254 ACWS (3d) 700 [Fondation internationale] (declaring a Muslim non-profit foundation to be a religious corporation eligible for a property tax exemption by analogy to Loyola High School).

264. Loyola, supra note 9 at para 32.

265. See Dwight Newman, Community and Collective Rights (Oxford: Hart Publishing, 2011) (arguing that collectivities have moral rights irreducible to those of their members provided that they meet certain conditions).

266. Ibid at 61. 
of an institution formed for the very purpose of transmitting Catholicism, can teach and learn about the Catholic faith. ${ }^{267}$

But earlier, Justice Abella equivocated between the individual and collective grounds of the right at stake, when she wrote that the Minister's action "represents a disproportionate, and therefore unreasonable interference with the values underlying freedom of religion of those individuals who seek to offer and who wish to receive a Catholic education at Loyola." ${ }^{268}$

A problem with Justice Abella's position is that it gives no definite place to religious institutions within a community. This leads to problems in cases of conflict or dissent. Applying the Abella approach, courts must ask what the interests of the community are and how the institution fosters them and adjudicate between the perceptions of different individual members regarding the institution's values, objectives, and decisions. But this is not the way that religious organizations work. They have appointed officials or representatives (though the forms of representation widely) who can take into consideration the interests of the community or its members, but once they render a decision, no further reference to interests needs to be made. To consider such interests after an institutional decision has been rendered is to violate the autonomy of the religious institution by substituting the court's judgment of the interests at stake for those of the religious officials.

The concurrent opinion implicitly recognizes this problem with the Loyola majority. The Chief Justice and Justice Moldaver seem concerned with protecting agents, whether individual or corporate, not inchoate communities. The concurrence speaks unequivocally of "Loyola's freedom of religion" and "the religious freedom of Loyola itself." 269 As a result, the concurrence must address the problem of discerning the belief of the religious institution itself, since "where the claimant is an organization rather than an individual, the sincerity of belief' inquiry required by our jurisprudence poses some difficulties"270 even though "a religious organization may in a very real sense have religious beliefs and rights." ${ }^{271}$ The concurrence's solution is to adapt the test of religious sincerity laid out in Amselem, with some modifications. While assessing the beliefs of a corporate agent is problematic, "an organizational claimant must show that the claimed belief or practice is consistent with both the purpose and operation of

267. Loyola, supra note 9 at paras 60-61.

268. Ibid at para 6 .

269. Ibid.

270. Ibid at para 135 .

271. Ibid at para 99. 
the organization."272 Here, the importance of the subjective-objective distinction brought up in Amselem is revealed. "It is proper to assess the claimed belief or practice in light of objective facts such as the organization's other practices, policies and governing documents. ... Therefore, inquiry into past practices and consistency of position would be more relevant than in the context of a claimant who is a natural person."273 The result is that the governance of religious institutions is made responsive to their formal decision-making structures. This may appear undemocratic at first, but it need not be so (since congregational religious institutions abound and are, in fact, the norm). In cases where it is undemocratic (as in hierarchical churches), deference is warranted precisely on grounds of religious liberty, as submission to an ecclesiastical hierarchy may itself be the object of sincere religious belief.

A second vector of disagreement concerns the reach of the protection of corporate or institutional religious rights. The spectre of the American reaction to Hobby Lobby $v E E O C$ seems to haunt the concurring judges, but the concern was already expressed by Chief Justice Dickson in Edwards. ${ }^{274}$ The majority opinion does not have this problem since it is concerned first with the religious interest and only tangentially with the religious agent. But the concurrent opinion must address it. Chief Justice McLachlin and Justice Moldaver's solution is to restrict the application of section 2(a) rights to organizations "constituted primarily for religious purposes, and ... [whose] operation accords with these religious purposes." 275 This caveat does not touch all the core cases, including houses of worship or religious schools and charities. These will likely be organized though special legislation and declare their purpose in their trust or charter instruments. It also does not necessarily exclude all business corporations. ${ }^{276}$ But even religious charities or churches may engage in activities that push the boundaries of the religious. Religious universities that train students for secular professions are a pressing problem, as the showdown between TWU Law School and the various law societies demonstrates.

Yet the contribution of religious institutionalism to the question of religious freedom is not restricted to the autonomy of corporate religious bodies claiming religious rights. The institutional dimension of religious liberty concerns the

272. Ibid at para 138 .

273. Ibid at para 139.

274. Edwards, supra note 162 at 153.

275. Loyola, supra note 9 at para 100.

276. One may imagine a religious bookstore or a kosher or halal butchery successfully arguing that its constitutive purpose and operation are inherently religious. 
intrinsically religious body itself. This is the legacy of the tradition of libertas ecclesiae. The question of whether a religious corporation may claim a right or an exemption under the aegis of religious liberty is answered not by asking about the legal form of the group-whether it is a trust, a corporation, or a non-profit entity-but by asking whether it is part of "the church" or its equivalent. Appreciating the distinction between corporate religious rights and religious institutionalism avoids the difficulties identified by Chief Justice Dickson in Edwards and reiterated by the concurring judges in Loyola. Respect for religious institutionalism is independent of any inquiry into shareholders' and directors' religious beliefs. Such beliefs will likely be aligned with the purposes of the religious body but are strictly speaking irrelevant to the claim brought by a religious body in its own right.

A third vector of disagreement concerns the reliance of both the majority and concurring opinions in Loyola on the state of positive law. The majority underlines "the character of lawful religious institutions," 277 but what would happen if confessional schools were simply abolished, as has been previously proposed in Quebec? The conclusion is paradoxical: The rights of religious institutions are only respected when those institutions are recognized by law. Two arguments might be marshalled to resist this conclusion. The first, following the majority, might argue that the rights of religious communities demand that the law allow them to create religious institutions to support and preserve the community. An alternative argument, more consistent with the tradition of religious institutionalism, would consider these institutions to exist independent of state recognition, formed according to their own precepts and legal norms.

The difference is subtle, but it has implications for the legal norms that ought to govern the institutions internally. Some religious organizations may easily fit into legal categories, such as not-for-profit corporations. But what about religious organizations whose internal structures, set up according to religious precepts, do not entirely square with the civil form that they have adopted or had imposed upon them? This is often the case with hierarchical churches that have a robust ecclesiastical legal tradition. Historically, Canadian courts were not consistent in the approach they used to review internal church disputes. ${ }^{278}$ Judges often overlooked hierarchical authority and internal church processes, looking instead

277. Loyola, supra note 9 at para 67.

278. Recall the deference shown in Ash. See Ash, supra note 128. 
at continuity of doctrine. ${ }^{279}$ But recently, courts have been less reluctant to turn towards ecclesiastical documents to discern the true character of the organization. ${ }^{280}$ The model seems closer to the concurrence than to the majority in Loyola, but it is too early to tell if the two jurisprudential lines will converge. There is reason to hope, however, that the two opinions are not too far apart in application. Both signal an institutionalist turn in Canadian jurisprudence. Although each opinion understands institutionalism in significantly different ways, even the majority acknowledges, in several paragraphs of carefully pondered qualifications, that the institutional religious setting demands flexibility and deference to the Catholic character of the school even in the teaching of non-Catholic topics. We are now a long way from Hutterian.

\section{CONCLUSION}

The purpose of this article is not to offer a detailed elaboration of a jurisprudential standard for cases involving churches and other religious bodies but only to suggest that such a standard must involve consideration of the institutional aspect of religious life. One important distinction between religion and conscience is that religious claims appeal to sources of authority that the believer places outside his or her individual conscience. While these sources of authority can be quite abstract (including the divinity directly, without human mediation), in practice they are often concrete, worldly institutions like churches, schools, and religious bodies. These structures are constitutive of religious belief and necessary for its practice. The history of freedom of religion shows this, and current legal controversies confirm it. As such, the institutional manifestations of religion

279. MH Ogilvie, "Church Property Disputes: Some Organizing Principles" (1992) 42:4 UTLJ 377. The approach used was that of finding an implied trust consistent with the original purpose of the congregation, understood in terms of continuity of doctrine. But for a reading of the implied trust doctrine arguably more congenial to the way the most recent jurisprudence has developed, see Alvin J Esau "The Judicial Resolution of Church Property Disputes: Canadian and American Models" (2003) 40:4 Alta L Rev 767 [Esau, "Judicial Resolution"].

280. See Pankerichan v Djokic, 2014 ONCA 709, 379 DLR (4th) 42 [Pankerichan]. Pankerichan accepted that "Canadian courts will not simply defer to the ecclesiastical judgments of church authorities about membership issues without judicially reviewing those decisions to ensure that they conform with the internal law of the religious group" (ibid at para 62, citing Esau, "Judicial Resolution," supra note 279 at 814 . But in nearly all cases, examination of internal documents has vindicated the hierarchy. See also Bentley, supra note 72; Delicata, supra note 99; United Church of Canada v Anderson (1991), 2 OR (3d) 304, 25 ACWS (3d) 601. 
should receive protections that are the same as or similar to those afforded to the individual manifestation of religion, especially in the case of religious educational institutions so essential to the preservation of communities of faith. These institutions should be allowed to claim the protection of their religious freedom to constitute themselves in accordance with their tenets, as this is the only viable way to protect the religious practice of their congregants.

The status of religious institutions remains a central issue in Canadian jurisprudence that will surely soon come back to the courts' attention. The Supreme Court of Canada recently denied leave to appeal an Alberta decision asserting the court's jurisdiction to order the restructuring of a Sikh religious society's membership as a remedy for religious officials' oppression of individual members, ${ }^{281}$ but such internal disputes are far from rare and the issue is likely to come up again soon. Indeed, there is pressure from an increasing number of lower court decisions relating to ecclesiastical property disputes, ministerial labour contracts, and the parameters of religious services, including religious education. Judicial approaches to these cases show no clear doctrinal consistency. Courts have given greater deference to the institutional hierarchy of religious bodies in property cases ${ }^{282}$ than in labour cases. ${ }^{283}$ The record is mixed in religious education cases, as illustrated most prominently by the split between courts of appeal in Ontario ${ }^{284}$ and New Brunswick ${ }^{285}$ over the accreditation of the proposed TWU Law School. But there are other cases involving services that a church considers central to its religious mission, but that would contravene statutory or administrative restrictions ${ }^{286}$ or be subject to different tax treatment ${ }^{287}$ if not sponsored by a religious body.

We claim that religious institutionalism can help clarify the issues at stake in some of these disputes because it better conforms to the historical trajectory of the idea of religious freedom, which includes strong claims to autonomy and self-governance by religious institutions. Religious institutionalism also helps

281. Sandhu v Siri Guru Nanak Sikh Gurdwara of Alberta, 2015 ABCA 101, 250 ACWS (3d) 257, leave to appeal to SCC refused, 36426 (13 August 2015).

282. See Pankerichan, supra note 280; Bentley, supra note 72; Delicata, supra note 99.

283. See e.g. Kong, supra note 100 at para 50.

284. Trinity Western University $v$ The Law Society of Upper Canada, 2015 ONSC 4250, 254 ACWS (3d) 753.

285. Trinity Western University v Nova Scotia Barristers' Society, 2015 NSSC 25, 248 ACWS (3d) 952.

286. See e.g. Sarnia v River City Vineyard Christian Fellowship of Sarnia, 2015 ONCA 494, 254 ACWS (3d) 947.

287. Fondation internationale, supra note 263, leave to appeal to QCCA granted. 
clarify some important ambiguities in the law and fills deep and troubling lacunae in current jurisprudence. It makes better sense of the statutory recognition of religious institutional authority and the philosophical concern over the nature and scope of such authority. The institutionalist conception of religious freedom also recognizes that religious institutions have an important structural role to play in supporting religious practice and thereby preserving the freedom of individual congregants. Therefore, it is necessary to take account of both the individualist and the institutionalist strains of religious liberty to give Charter protections their due.

The long line of cases in which the Supreme Court of Canada has tried to define and delimit the concept of religious freedom has tended to focus exclusively on individual freedom of religious conscience and ignored or downplayed institutional religious liberty. With the exception of Hutterian, most of these cases have not had to confront the institutional dimension head on. This made it easier to put aside the doctrinal consequences of constructing a concept of religious freedom that only considered individual consciences and ignored institutional subjects. Loyola was an excellent opportunity to recognize religious institutions but instead revealed the lingering divisions over the status of religious organizations. These divisions reflect the need for a historical, conceptual, and constitutional framework to deal with religious organizations when individualist doctrine does not fit the history and practice of religious bodies. Religious institutionalism can provide this framework. 
